Kuzhan, M. ve Fidan, M. (2020). Türkçe eğitiminde bilişim ve teknoloji kullanımına yönelik araştırmaların konu alanı ve yöntem yönünden analizi. Ana Dili Eğitimi Dergisi, 8(4), 1343-1367.

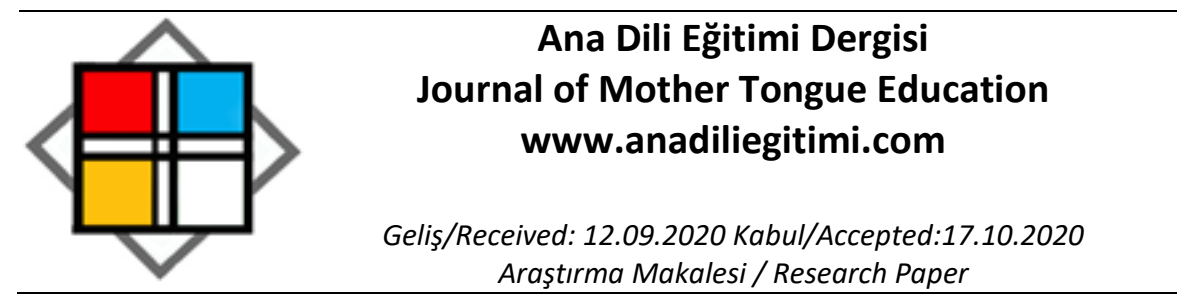

\title{
Türkçe Eğitiminde Bilişim ve Teknoloji Kullanımına Yönelik Araştırmaların Konu Alanı ve Yöntem Yönünden Analizi
}

\author{
Metin KUZHAN* \\ Mehmet FIDAN**
}

\begin{abstract}
Öz
Türkçe eğitimi süreçleri bireylerin anlama, anlatma kabiliyetlerine; bilişsel düşünme becerilerine vb. doğrudan etkide bulunduğu için araştırmacıların ilgi odağında yer alır. Bu araştırmalar genel olarak Türkçe eğitimi süreçlerinden daha etkin bir biçimde nasıl faydalanılacağı ve mevcut uygulamaların etkililiği doğrultusundadır. Eğitim süreçlerinin etkinliğinin geliştirilmesinde mevcut teknolojik imkânlardan yararlanılması konusu ön plana çıkmaktadır. Bu araştırmada Türkçe eğitimi süreçlerinde bilişim ve teknoloji kullanımına yönelik araştırmalar incelenmiştir. Bu araştırmalar lisansüstü tez çalışmaları ve makaleler şeklinde ele alınmıştır. Ele alınan araştırma örnekleri konu alanları ve yöntemleri yönünden analiz edilmiştir. Araştırmada tarama modelinden yararlanılmıştır. Verilere ulaşmada doküman incelemesi, verilerin değerlendirilmesinde ise içerik analizi kullanılmıştır. Tezler ve makaleler sıralanan alanlar açısından ayrı ayrı değerlendirilmiştir. Araştırma sonuçları özetlendiğinde tezlerde konu alanı yönünden "çoklu ortam-dil becerileri etkileşimi”, "yabancılara Türkçe öğretim süreçlerinde e-içerik kullanımı", "e-içerik-dil becerilerinin etkileşimi" vb.; makalelerde ise "yabancılara Türkçe öğretim süreçlerinde e-içerik, teknoloji kullanımı" ve "teknoloji, bilgisayar destekli Türkçe eğitimi" başlıklarının ön plana çıktığı tespit edilmiştir. Lisansüstü tezlerde ön test-son test kontrol gruplu deneysel desenin, makalelerde ise tarama modellerinin en çok kullanılan araştırma modelleri olduğu görülmüştür.
\end{abstract}

Anahtar Kelimeler: Türkçe eğitimi, bilişim teknolojileri, eğitim süreçlerinin geliştirilmesi

\section{Analysis of Studies on Use of Informatics - Technology in Turkish Education in Terms of Subject Area and Method}

\begin{abstract}
Turkish education processes are in the focus of attention of researchers because they directly affect individuals' understanding, expression skills, scientific thinking skills, etc. In general, these studies are aimed at how to make more effective use of Turkish education processes and the effectiveness of existing practices. In the development of the effectiveness of educational processes, the issue of using existing technological opportunities comes to the fore. In this study, research on the use of information and technology in Turkish education processes was examined. These researches are handled in the form of postgraduate thesis and articles. The research samples were analyzed in terms of subject areas and methods. The screening model was used in the study. Content analysis was used for document review and data evaluation. Theses and articles were evaluated separately in terms of the listed fields. In general, the research results are summarized in theses in terms of the subject area of multimedia-language skills interaction and the use of e-content in Turkish teaching processes for foreigners and the interaction of econtent-language skills, etc.; In the articles, it has been determined that the titles of e-content,
\end{abstract}

\footnotetext{
* Öğretmen, Bahçelievler Türk Telekom MTAL, İstanbul, metinkuzhan@hotmail.com, ORCID: 0000-0001-64208327

** Dr. Öğr. Üyesi, Aksaray Üniversitesi, Eğitim Fakültesi, Türkçe ve Sosyal Bilimler Eğitimi Bölümü, Aksaray, fidanm3838@gmail.com, ORCID: 0000-0002-9347-2992
} 
use of technology and technology, computer-aided Turkish education have come to the fore in the processes of teaching Turkish to foreigners. In graduate dissertations, it was observed that the experimental pattern with pre test-final test control group and the screening models in articles were the most commonly used research models.

Keywords: Turkish education, information technologies, development of educational processes

\section{Giriş}

Ana dili eğitimi, yabancılara Türkçe öğretimi, dil bilgisi gibi çeşitli alanları içerisinde barındıran Türkçe eğitimi, öğrencilerin hem akademik hem dil becerileri yönünden gelişiminde önemli bir konumda bulunur. Bu durum Türkçe eğitimi alanının teoride ve uygulamada çok boyutlu olmasına katkı sağlamaktadır. Banguoğlu (2015: 7) Türkçenin 1300 yıllık yazı dili geleneği ile "ileri medeniyetlerin taşıyıcısı" olduğunu ifade eder. Ayrıca Türkçe eğitimi alanının ulusal kültür ögelerini öğrencilere kazandırmada da rolünün olduğu görülür (Göçer, 2018: 7). Buna ek olarak "çocuk çevresini, toplumunu ve bu toplumun koyduğu ve geliştirdiği kültürel birikimi anadiliyle algılayıp kavramaktadır" (Sever, 2011: 1). Türkçe eğitiminin bu genel özellikleri onun dil, kültür, eğitim gibi yönlerden birçok araştırmacı tarafından incelenmesine katkı sağlamıştır.

Türkçe derslerinin öğrenme ve öğretim süreçleri açısından etkililiğinin geliştirilmesi için yapılandırmacı yaklaşım doğrultusunda tasarlanan yöntem ve tekniklere ek olarak gelişen teknolojinin de -diğer branşlarda olduğu gibi- eğitim öğretim ortamına aktarılmasına ve kullanılmasına imkân oluşturulmaya çalışıldığı görülmektedir. Bu açıdan dinleme, konuşma, okuma ve yazma olarak tanımlanan dil becerilerinin geliştirilmesinde, öğrencilere millî, manevi kültür değerlerinin benimsetilmesinde, kısacası bireyleri hayata hazırlamada (MEB, 2019: 3) etkili olduğu görülen yöntem ve teknikler Türkçe eğitimi süreçlerinde kullanılmaktadır. Ayrıca burada eğitim süreçlerinin yalnızca öğrencilerle sınırlandırılmadığı, bu alanda öğretmen yeterliliklerine de önem verildiği yapılan araştırmaların konu alanları (Yaman, 2007; Akın, 2015; Maden, 2019) incelendiğinde görülebilmektedir.

TDK'nin (2020) Güncel Türkçe Sözlük'ünde bilişim, “insanoğlunun teknik, ekonomik ve toplumsal alanlardaki iletişiminde kullandığı ve bilimin dayanağı olan bilginin özellikle elektronik makineler aracılığıyla düzenli ve akla uygun bir biçimde işlenmesi bilimi, enformatik." şeklinde tanımlanır. Tanımdan yola çıkarak bilişim kavramı yorumlandığında özellikle elektronik makine, bilginin işlenmesi, bilgiye ulaşım gibi kavramların dikkat çektiği görülür. Bilişim ve elbette bu alanın bir diğer kavramı olan teknolojinin yukarıda sıralanan bu özellikleri eğitim süreçlerinin bu niteliklerle donatılmasını gerektirmektedir. Özellikle son dönemde eğitim süreçlerinin uygulanmasında bilişim ve teknolojiden geniş ölçüde faydalanılması bu alanda EBA gibi uygulamaların etkililiğini ortaya koymaktadır.

Türkçe eğitimi alanında bilişim ve teknoloji kullanımına yönelik araştırmaların özellikle son dönemde daha fazla olduğu görülmektedir. Bu araştırmalarda hangi alanların uzmanlarca ele alındığı incelendiğinde tasarlanan web programlarının etkililiği, derslerde çoklu ortamın sağlanabilirliği, bilişim ve iletişim araçlarının dil becerilerine etkisi, öğretmen ve öğrenci yeterlilikleri gibi konuların olduğu gözlenmektedir. Arıcı ve Karacı (2013: 86) araştırmalarında Türkçe eğitimi alanında geliştirilen internet tabanlı bir uygulamanın etkililiğini araştırıp uygulamanın hem ana dili hem de yabancılara Türkçe öğretimi alanında kullanılabileceğini belirtmişlerdir. Bayburtlu (2019: 373) ise araştırmasına katılan Türkçe öğretmenlerinin genelinin "sosyal ağlar ve sanal öğrenme ortamları" konusunda bilgili olduklarını, bu tür uygulamaları kullandıklarını tespit etmiştir. Yavuz ve Coşkun (2008: 281) çalışmalarında teknoloji destekli proje çalışmalarının öğrencilerin bu türden araç-gereçleri kullanma yönündeki tutumlarını olumlu yönde etkilediğini tespit etmişlerdir.

Yapılan araştırmalarda öğretmen adaylarına yönelik çalışmaların da olduğu görülmektedir. Şahin ve Akçay (2011: 909) Türkçe öğretmeni adaylarının Türkçe derslerinin bilgisayar destekli işlenmesi konusunda öğretmen adaylarının sınıf düzeyleri ile bilgisayar destekli ders işleme konusundaki tutumlarının aynı yönde arttığını belirtmektedir. Yaman, Demirtaş, Aydemir (2013: 1407) araştırmalarında bilişim teknolojilerini kullanma yönünden yetkin öğretmen adaylarının "dijital pedagoji" açısından da yetkin olduklarını tespit etmiştir. Akçay ve Özcan (2012: 151) ise 
araştırmalarında Türkçe öğretmeni adaylarının bilişim alanındaki yabancı kelimelerin Türkçe karşııklarını bilme konusunda yeterli olmadıklarını ifade etmektedir.

Yabancılara Türkçe öğretimi alanında bilişim ve teknolojiden yararlanılması konusunun da araştırmacıların dikkatini çektiği görülmektedir. Becel (2014: 106) yabancılara Türkçe öğretimi alanında kullanılabilecek bir uygulamayı incelediği araştırmasında, ele alınan uygulamanın eğitsel yönden yeterli olmadığını ancak "görünürlük ve ulaşılabilirlik" açısından önemli olduğunu belirtmektedir. Türker (2019: 574) yabancılara Türkçe öğretimi alanında eğitim veren öğretmenlerin "eğitim teknolojisi standartları öz yeterlik algılarının yüksek düzeyde olduğunu" tespit etmiştir. İskender ve Gücüyeter (2019: 571) yabancılara Türkçe öğretimi süreçlerinde bir sosyal medya uygulamasının etkinliklerde kullanılmasının öğrencilerin yazma becerilerinin geliştirilmesine olumlu etkisinin olduğunu ifade etmektedir.

EBA (Eğitim Bilişim Ağı), öğrencilerin ve öğretmenlerin sınıf içi-dışı eğitim faaliyetlerini destekleyici konumda bulunmaktadır. Bu konuda Aktay ve Keskin (2016: 43) EBA'nın sunduğu ders içerikleri, ulaşılabilirlik, uygulamalar gibi özelliklerin eğitsel açıdan önemli olduğunu belirtir. Özellikle okullarda teknolojinin yaygın kullanımı EBA'nın içerik sağlama açısından sıklıkla başvurulan bir ekaynak olmasına imkân sağlamaktadır. EBA'nın bu özelliği diğer branşların yanında Türkçe dersleri açısından da etkililiğinin araştırılmasını beraberinde getirmiştir. Bu araştırmaların genel olarak incelendiğinde EBA ile Türkçe Dersi Öğretim Programı uyumu (İskender, 2016), öğrencilerin bu uygulamaya yönelik tutumları (Timur, Yılmaz, İşseven, 2017; Can, Topçuoğlu Ünal, 2018), uygulamada yer alan eğitsel etkinliklerin incelenmesi (Candeğer, Mete, Büyükköse, 2017) gibi alanlarda olduğu görülmektedir. Bu konudaki çalışmasında Bayburtlu (2020: 134) Türkçe öğretmenlerinin EBA ile ders kitapları arasında etkileşimin olmasının eğitsel süreçlere olumlu yönde katkısının olacağını belirttiklerini ifade eder.

\section{Araştırmanın Modeli}

\section{Yöntem}

Tarama modelinin kullanıldı̆̆ı bu araştırmanın amacı, Türkçe dersi öğretim süreçlerinde bilişim ve teknolojiden yararlanılması konusunda yapılan araştırmaların konu alanlarının ve yöntemlerinin analizidir. Bu doğrultuda konu alanı ile ilgili lisansüstü tezler ve makaleler incelenmiştir. Bu araştırmada cevabı aranan sorular şu şekildedir:

1. Türkçe dersi öğretim süreçlerinde bilişim ve teknolojiden yararlanılması konusunda yapılan araştırmalar hangi konu alanları altında yer almaktadır?

2. Türkçe dersi öğretim süreçlerinde bilişim ve teknolojiden yararlanılması konusunda yapılan araştırmaların yöntem özellikleri nelerdir?

\section{Örneklem}

Bu araştırmanın örneklemi Türkçe öğretim süreçlerinde bilişim ve teknolojiden yararlanılması konusunda yapılan araştırmalardır. Bu araştırmalar lisansüstü tezler ve makaleler şeklinde sınıflandırılmıştır. Araştırma sürecinde konu yönünden uygun olan bazı bildiriler de örnekleme dâhil edilmiş ve bu bildiriler sayı olarak az olmalarından dolayı makale grubunda değerlendirilmiştir. Yapılan literatür taramasında araştırma konusuna yönelik çalışmaların yoğun olarak lisansüstü tez ve makale olarak yer aldığının görülmesi sebebiyle araştırma alanı bu şekilde sınırlandırılmıştır. Bu doğrultuda araştırmada amaçlı örnekleme yapılmıştır. Yıldırım ve Şimşek (2008: 107) bu örnekleme yönteminin "pek çok durumda, olgu ve olayların keşfedilmesinde ve açıklanmasında yararlı" olduğunu ifade eder.

Araştırmada ilgili çalışmalara ulaşılmasında izlenen yöntem şu şekildedir: Araştırma konusu ile ilgili tezlere erişilmesi için https://tez.yok.gov.tr/UlusalTezMerkezi'ne başvurulmuştur. Burada tarama terimi olarak "Türkçe eğitimi" kavramı kullanılmıştır. Tarama sonucunda ulaşılan tezlerden bilişim teknolojileri alanı ile bağlantılı olan çalışmalar iki araştırmacı tarafından tespit edilmiştir. Araştırma sürecinde incelenen tezlerin Türkçe eğitimi, yabancı dil olarak Türkçe öğretimi, yabancılara Türkçe öğretimi, sınıf öğretmenliği gibi ana bilim dallarında olduğu görülmüştür. Bu aşamada erişim izni olmayan tezler araştırmaya dâhil edilmemiştir. Bu yöntemle toplamda 44 lisansüstü teze 
ulaşılımıştır. Araştırma konusu ile ilgili makalelere erişilmesinde ise Google Scholar, ERIC, SOBIAD gibi indeksler taranmıştır. Bu indekslerden tarama yapılırken Türkçe eğitimi, bilişim, teknoloji, EBA, uzaktan eğitim gibi terimler kullanılmıştır. İki araştırmacı tarafından bu indekslerde yapılan taramalar sonucunda ulaşılan makaleler konu alanı yönünden Türkçe eğitiminde bilişim ve teknoloji kullanımı yönünden seçilmiştir. Bu süreçte toplamda 76 makaleye ulaşılmıştır. Lisansüstü tezler ve makalelerle birlikte 120 çalışmanın Türkçe eğitimi süreçlerinde bilişim ve teknoloji kullanımı ile ilgili olduğu görülmüş, bu çalışmalar araştırma sürecine dâhil edilmiştir.

Tezlerin ve makalelerin konu alanları yönünden sınıflandırılmasında ilgili çalışmaların başlıkları, anahtar kelimeleri, özetleri ve yöntemleri incelenmiştir. Bu aşamada bazı çalışmaların konu alanlarının birden fazla başlık altında yer aldığı tespit edilmiştir. Araştırma sürecinde incelenen lisansüstü tezlere ve makalelere yönelik bilgiler ekte yer almaktadır.

\section{Veri Toplama Araçları}

Verilere ulaşılmasında doküman incelemesi yönteminden faydalanılmıştır. Yıldırım ve Şimşek (2008: 188) araştırma süreçlerinde dokümanların önemlerinin belirlenmesinde ve veri kaynağı seçiminde araştırma problemlerinden faydalanıldığını belirtir. Bu doğrultuda araştırmada lisansüstü tezlere ulaşılmasında YÖK Tez Merkezi; makalelere ulaşılmasında ise Google Scholar, ERIC, SOBIAD gibi indeksler kullanılmışır. Araştırmada veri kaynaklarına erişilmesi aşamasında Türkçe eğitimi, bilişim, teknoloji gibi tarama terimleri kullanılmış, çıkan sonuçlar araştırmacılar tarafından çalışma konusuna uygunluk ve konu alanları yönünden sınıflandırılmıştır. Bu aşamada elde edilen veriler fişleme metodu kullanılarak tezler ve makaleler olarak ayrı ayrı gruplandırılmıştır.

\section{Verilerin Analizi}

Bu araştırmada içerik analizi yönteminden yararlanılmıştır. Yıldırım ve Şimşek (2008:227) bu analiz yönteminde "toplanan verileri açıklayabilecek kavramlara ve ilişkilere ulaşma"nın temel amaç olduğunu, bu yöntemin verilerin derinlemesine incelenmesi vasıtasıyla kavram ve temaların keşfedilmesine imkân sağlayabildiğini ifade eder. Bu araştırmada Yıldırım ve Şimşek (2008: 232) tarafından "verilerden çıkarılan kavramlara göre yapılan kodlama" şeklinde ifade edilen kodlama yöntemi kullanılmıştır. Araştırmada lisansüstü tezler ve makaleler konu alanları yönünden sınıflandırılmıştır. Bu çalışmaların konu alanları yönünden sınıflandırılmasında verilerin daha sade biçimde ifade edilmesi amacıyla grafikler kullanılmıştır. Daha sonra incelenen çalışmaların konu alanları yönünden frekans değerleri hesaplanmıştır. Bu durum hangi konu alanları yönünden çalışmaların gruplandığının belirlenmesine ve frekans değerleri kullanılarak hangi alanlarda daha fazla ve daha az çalışmanın olduğunun tespit edilmesine katkı sağlamıştır.

Verilerin konu alanı yönünden grafik hâline getirilmesinde dinleme, konuşma, okuma ve yazma kavramları dil becerileri şeklinde gruplandırılmıştır. Türkçe derslerinde görüntü, ses gibi ögelerin kullanılması çoklu (teknoloji destekli) ortam başlığı altında gruplandırımıştır. Bilgisayar oyunları da bilgisayarın dil becerilerine etkisi şeklinde tanımlanmıştır. Medya okuryazarlığına yönelik araştırmalar iletişim araçları şeklinde tanımlanmıştır. TV, iletişim araçları içerisinde yer almış, çizgi filmler ise incelenen çalışmalarda özel olarak vurgulandığı için müstakil bir alan içerisinde değerlendirilmiştir. Bu doğrultuda derslerde teknoloji kullanımı konusunda da sosyal medya ve uzaktan öğretim alanları da incelenen çalışmalarda özel olarak vurgulandığı için ayrı konu alanları şeklinde ele alınmıştır.

$\mathrm{Bu}$ araştırmada incelenen lisansüstü tezlerin ve makalelerin yöntem özelliklerinin belirlenmesi aşamasında ilgili eserlerin yöntem bölümleri incelenmiştir. Bu doğrultuda çalışmalar model, örneklem-çalışma grubu, veri toplama araçları, verilerin analizi başlıkları altında değerlendirilmiştir. Bu durumun Türkçe eğitimi süreçlerinde bilişim teknolojilerinden yararlanılması konusundaki çalışmaların yöntem özellikleri konusunda detaylı verilere ulaşılmasına katkı sağlaması amaçlanmıştır. İgili çalışmalar model, örneklem-çalışma grubu, verilerin analizi tabloları şeklinde sunulmuş ve yine bu tablolar frekans özellikleri açısından ifade edilmiştir. Frekans ifadesi (F) şeklinde kısaltılarak verilmiş̧tir. Verilerin değerlendirilmesinde SPSS 20 programından faydalanılmıştır. 
Türkçe eğitiminde bilişim ve teknoloji kullanımına yönelik araştırmaların konu alanı ve yöntem yönünden analizi

Lisansüstü Tezlerin Konu Alanları Yönünden İncelenmesi

\section{Bulgular}

Türkçe eğitimi süreçlerinde bilişim ve teknolojinin kullanımını inceleyen lisansüstü tezler konu alanları yönünden değerlendirilmiş ve elde edilen veriler Grafik 1'de sunulmuştur.

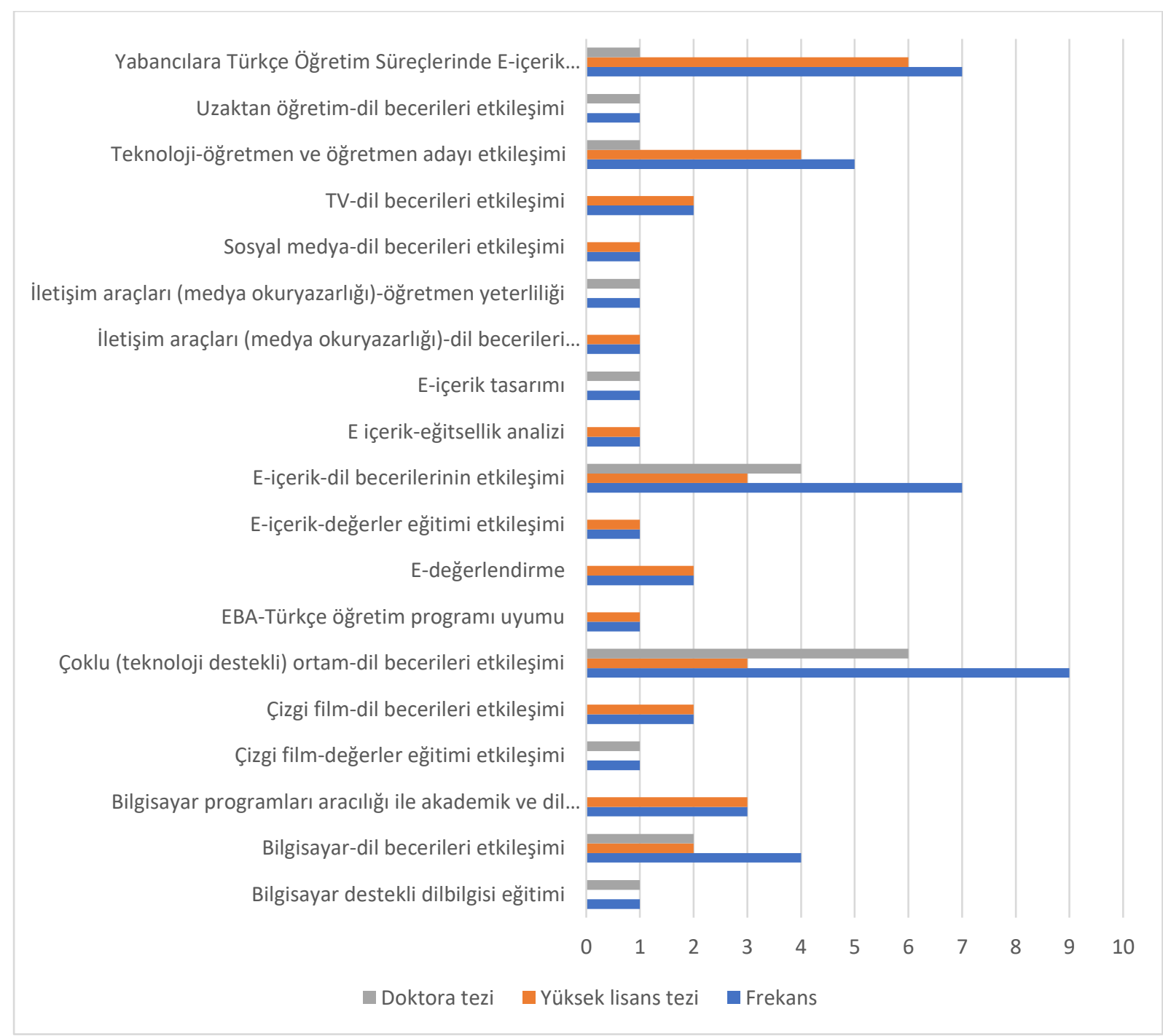

Grafik 1. Tezlerin konu alanları

Grafik 1 yorumlandığında toplamda 19 konu alanının yer aldığı görülmektedir. Türkçe eğitimi süreçlerinde bilişim ve teknolojinin kullanımına yönelik yapılan lisansüstü tezlerde en çok araştırılan konu alanı "çoklu ortam-dil becerileri etkileşimi" olmuştur (F:9). Bu tezlerden 6'sı doktora tezi, 3'ü ise yüksek lisans tezidir. Aynı zamanda "çoklu ortam-dil becerileri etkileşiminin" konu alanları içerisinde doktora tezleri açısından en yüksek frekansa sahip olduğu tespit edilmiştir.

"Yabancılara Türkçe öğretim süreçlerinde e-içerik kullanımı" ve "e-içerik-dil becerilerinin etkileşimi" konu alanlarının frekanslarının eşit olduğu tespit edilmiştir (F:7). "Yabancılara Türkçe öğretim süreçlerinde e-içerik kullanımına" yönelik tezlerden 6'sı yüksek lisans, 1'i ise doktora tezidir. Diğer konu alanları ile karşılaştırıldı̆ıında en fazla yüksek lisans tezinin "yabancılara Türkçe öğretim süreçlerinde e-içerik kullanımı" alanında olduğu görülmektedir. "E-içerik-dil becerilerinin etkileşimi" konu alanında 4 çalışmanın doktora, 3 çalışmanın ise yüksek lisans tezi olduğu tespit edilmiştir.

"Teknoloji-öğretmen ve öğretmen adayı etkileşimi" konu alanında 4'ü yüksek lisans, 1'i doktora olmak üzere toplam 5 tezin olduğu görülmüştür (F:5). "Bilgisayar-dil becerileri etkileşimi" konu alanında 2 doktora, 2 yüksek lisans (F:4); "bilgisayar programları aracılığı ile akademik ve dil 
becerileri gelişimi" konu alanında ise 3 yüksek lisans (F:3) tezinin olduğu tespit edilmiştir. "Çizgi filmdil becerileri etkileşimi", "e-değerlendirme", "TV-dil becerileri etkileşimi" konu alanlarında ise ikişer yüksek lisans tez çalışması yapılmıştır (F:2). "Bilgisayar destekli dilbilgisi eğitimi", "çizgi film-değerler eğitimi etkileşimi", "e-içerik tasarımı", "iletişim araçları (medya okuryazarlığı)-öğretmen yeterliliği" ve "uzaktan öğretim-dil becerileri etkileşimi" alanlarında ise 1'er doktora tezinin yapıldığı tespit edilmiştir (F:1). "EBA-Türkçe öğretim programı uyumu", "e-içerik-değerler eğitimi etkileşimi", "eiçerik-eğitsellik analizi", "iletişim araçları (medya okuryazarlığı)-dil becerileri etkileşimi", "sosyal medya-dil becerileri etkileşimi" alanlarında da birer yüksek lisans tezinin yapıldığı görülmüştür (F:1).

\section{Makalelerin Konu Alanları Yönünden İncelenmesi}

Türkçe eğitimi süreçlerinde bilişim ve teknolojinin kullanımını inceleyen makaleler konu alanları yönünden değerlendirilip elde edilen veriler Grafik 2'de sunulmuştur.

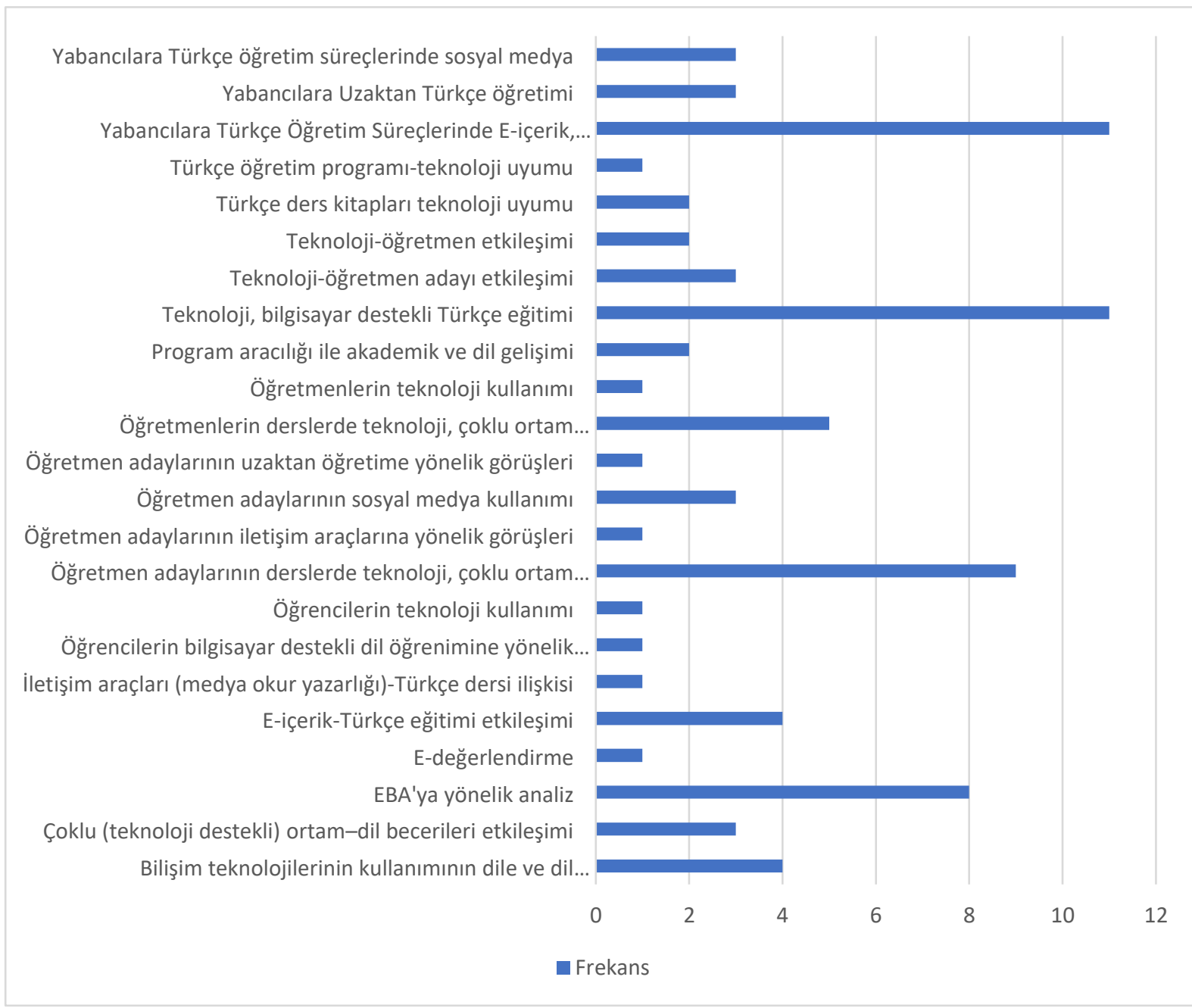

Grafik 2. Makalelerin konu alanları

Grafik 2 yorumlandığında toplamda 23 konu alanı bulunmaktadır. Türkçe eğitimi süreçlerinde bilişim ve teknolojinin kullanımına yönelik makalelerde en çok araştırılan konuların "yabancılara Türkçe öğretim süreçlerinde e-içerik, teknoloji kullanımı" ve "teknoloji, bilgisayar destekli Türkçe eğitimi" olduğu görülmektedir (F:11). Yabancılara Türkçe eğitimi alanına yönelik çalışmaların hem tezlerde hem de makalelerde çokluk göstermesi araştırmacıların bu alana ilgilerinin göstergesi niteliğindedir. Bu araştırmada incelenen makalelerden 9 tanesinin "öğretmen adaylarının derslerde teknoloji, çoklu ortam kullanımına yönelik görüşleri" konu alanında olduğu tespit edilmiştir (F:9). "EBA'ya yönelik analiz" konu alanının da yine makalelerde öncelikli olarak ele alındığı görülmektedir 
(F:8). Ancak tezlerde ise EBA'ya yönelik araştırmaların makalelere göre daha az olduğu söylenebilir $(\mathrm{F}: 1)$.

"Öğretmenlerin derslerde teknoloji, çoklu ortam kullanımına yönelik görüşleri" konu alanında 5, "bilişim teknolojilerinin kullanımının dile ve dil becerilerine etkisi" ve "e-içerik-Türkçe eğitimi etkileşimi" konu alanlarında ise dörder makalenin bulunduğu tespit edilmiştir (F:5, F:4).

Grafik 2 yorumlandığında "Çoklu (teknoloji destekli) ortam-dil becerileri etkileşimi", "öğretmen adaylarının sosyal medya kullanımı", "teknoloji-öğretmen adayı etkileşimi”, "yabancılara uzaktan Türkçe öğretimi" ve "yabancılara Türkçe öğretim süreçlerinde sosyal medya" konu alanlarında ise üçer makale çalışmasının olduğu görülmektedir (F:3). "Program aracılığı ile akademik ve dil gelişimi", "teknoloji-öğretmen etkileşimi", "Türkçe ders kitapları teknoloji uyumu" konu alanlarında ikişer makale çalışması bulunmaktadır ( $F: 2$ ).

"E- değerlendirme", "iletişim araçları (medya okuryazarlığı)-Türkçe dersi ilişkisi", "öğrencilerin bilgisayar destekli dil öğrenimine yönelik görüşleri", "öğrencilerin teknoloji kullanımı", "öğretmen adaylarının iletişim araçlarına yönelik görüşleri", "öğretmen adaylarının uzaktan öğretime yönelik görüşleri”, "öğretmenlerin teknoloji kullanımı" ve "Türkçe öğretim programı-teknoloji uyumu" konu alanlarında birer makalenin bulunduğu görülmüştür ( $F: 1)$. Araştırma sürecinde incelenen tezlerin makalelere göre daha az olmasına karşın "E-değerlendirme" konu alanında tez çalışmaları makalelere göre daha fazladır (F:4). Genel olarak e-içerik konu alanlarında da tez çalışmalarının daha fazla olduğu söylenebilir (F:10).

\section{Lisansüstü tezlerin araştırma modelleri yönünden incelenmesi}

Türkçe eğitimi süreçlerinde bilişim ve teknolojinin kullanımını inceleyen lisansüstü tezler kullanılan araştırma modelleri yönünden değerlendirilip elde edilen veriler Tablo 1'de sunulmuştur.

Tablo 1.

Lisansüstü tezlerin kullanılan araştırma modellerine göre dağııımı

\begin{tabular}{lll}
\hline Sıra & Araştırma Modeli & Frekans \\
\hline 1 & Ön Test-Son Test Kontrol Gruplu Deneysel Desen & 17 \\
2 & Tarama Modeli & 4 \\
3 & Betimsel Tarama Modeli & 5 \\
4 & Deneysel & 1 \\
5 & Eş Zamanlı Dönüşümsel Tasarım Modeli & 1 \\
6 & Özel Durum Çalışması Yöntemi & 1 \\
7 & Karma Yöntem & 11 \\
8 & Durum Çalışması & 3 \\
9 & Eylem Araştırması & 3 \\
10 & Açıklayıcı Desen & 1 \\
11 & Zenginleştirilmiş Desen & 1 \\
12 & Keşfedici Desen & 1 \\
13 & İ̧̧ İ̧̧e Gömülü Desen & 1 \\
14 & ilişkisel Tarama Modeli & 3 \\
15 & Split-Plot Faktöryel (Karışık) Desen & 1 \\
16 & Açımlayıcı Sıralı Desen & 2 \\
17 & Tasarım Tabanlı Araştırma (TTA) & 1 \\
18 & Statik Grup Karşılaştırmalı Desen & 1 \\
19 & Nitel Desen & 1 \\
20 & Tek Noktada Birleştirme & 1 \\
\hline
\end{tabular}

Tablo 1 yorumlandığında toplamda 20 adet araştırma modelinin yer aldığı görülmektedir. Türkçe eğitimi süreçlerinde bilişim ve teknolojinin kullanımına yönelik yapılan lisansüstü tezlerde en çok kullanılan araştırma modeli “ön test-son test kontrol gruplu deneysel desen” olmuştur (F:17). 
"Karma yöntem" incelenen lisansüstü tezlerde ikinci en çok kullanılan araştırma modelidir (F:11). Bunların haricinde "tarama" (F:4) ve "betimsel tarama" (F:5) araştırma modellerinin sırasıyla daha çok tercih edildiği görülmüştür.

"Durum çalışması", "eylem araştırması", "ilişkisel tarama modeli" araştırma modellerinin incelenen tezlerde kullanım frekansları eşittir (F:3). "Açımlayıcı sıralı desene" ise yukarıda sıralanan araştırma modellerine göre daha az başvurulmuştur (F:2).

"Deneysel", "eş zamanlı dönüşümsel”, “özel durum çalışması", “açıklayıcı desen", "zenginleştirilmiş desen", "keşfedici desen”, "iç içe gömülü desen", "karışık desen", "tasarım tabanlı araştırma", "statik grup karşılaştırmalı desen", "nitel desen" ve "tek noktada birleştirme" araştırma modelleri ise incelenen lisansüstü tezlerde en az sayıda kullanılan araştırma modelleri olmuştur ( $F: 1)$.

\section{Makalelerin araştırma modelleri yönünden incelenmesi}

Türkçe eğitimi süreçlerinde bilişim ve teknolojinin kullanımını inceleyen makaleler kullanılan araştırma modelleri yönünden değerlendirilmiş ve elde edilen veriler Tablo 2'de sunulmuştur.

Tablo 2.

Makalelerin kullanılan araştırma modellerine göre dağııımı

\begin{tabular}{lll}
\hline Sıra & Araştırma Modeli & Frekans \\
\hline 1 & E-Öğrenme & 4 \\
2 & Literatür Tarama & 21 \\
3 & Betimsel Tarama & 8 \\
4 & Tarama Modeli & 15 \\
5 & Karma Model & 3 \\
6 & Yazın Taraması & 1 \\
7 & Ön Test-Son Test Kontrol Gruplu Deneysel Desen & 7 \\
8 & Nitel Araştırma & 13 \\
9 & Durum Çalışması & 7 \\
10 & Doküman İncelemesi & 5 \\
11 & ilişkisel Tarama & 3 \\
12 & Açımlayıcı Sıralı & 2 \\
13 & Örnek Olay İncelemesi & 1 \\
14 & Statik Grup Karşılaştırması & 1 \\
\hline
\end{tabular}

Tablo 2 yorumlandığında toplamda 14 adet araştırma modelinin yer aldığı görülmektedir. Türkçe eğitimi süreçlerinde bilişim ve teknolojinin kullanımına yönelik yapılan makalelerde en çok kullanılan araştırma modelinin "literatür tarama" olduğu tespit edilmiştir (F:21).

"Tarama modeli" incelenen makalelerde ikinci olarak en yüksek kullanılan model olmuştur (F:15). Bunlara ek olarak "nitel araştırma" (F:13) ve "betimsel tarama" (F:8) araştırma modellerinin sırasıyla kullanıldığı görülmüştür.

"Durum çalışması" ve "ön test-son test kontrol gruplu deneysel desen" araştırma modellerinin kullanım frekansları eşittir (F:7). Bununla beraber "ilişkisel tarama" ile "karma modelin" de frekansları eşittir (F:3). "Doküman incelemesi" (F:5), "e-öğrenme" (F:4) araştırma modeline göre daha fazla kullanılmıştır. "Açımlayıcı sıralı desenin" ise yukarıda incelenen araştırma modellerine göre daha az kullanıldığı görülmektedir (F:2).

"Yazın taraması", "örnek olay incelenmesi", "statik grup karşılaştırması" araştırma modelleri ise incelenen makalelerde en az sayıda kullanılan araştırma modelleri olmuştur ( $F: 1)$. 
Türkçe eğitiminde bilişim ve teknoloji kullanımına yönelik araştırmaların konu alanı ve yöntem yönünden analizi

\section{Lisansüstü tezlerin çalışma grupları yönünden incelenmesi}

Türkçe eğitimi süreçlerinde bilişim ve teknolojinin kullanımını inceleyen lisansüstü tezler kullanılan çalışma grupları yönünden değerlendirilip elde edilen veriler Tablo 3'te sunulmuştur.

Tablo 3.

Lisansüstü tezlerin kullanılan çalışma gruplarına göre dağılımı

\begin{tabular}{lll}
\hline Sıra & Çalışma Grubu & Frekans \\
\hline 1 & Illköğretim 3. Sınıf Öğrencileri & 1 \\
2 & İköğretim 5, 6, 7, 8. Sınıf Öğrencileri & 3 \\
3 & İköğretim 5, 6. Sınıf Öğrencileri & 1 \\
4 & Illköğretim 5. Sınıf Öğrencileri & 1 \\
5 & Ilköğretim 6. Sınıf Öğrencileri & 9 \\
6 & Ilköğretim 7. Sınıf Öğrencileri & 1 \\
7 & İlköğretim 6, 7, 8. Sınıf Öğrencileri & 2 \\
8 & Ilköğretim 8. Sınıf Öğrencileri & 4 \\
9 & Lisans Öğrencileri & 6 \\
10 & Okul Öncesi Öğrencileri & 2 \\
11 & Ilkokul Öğrencileri & 1 \\
12 & Veliler & 3 \\
13 & Öğretmenler & 8 \\
14 & Yabancı Öğrenciler (Lisans) & 4 \\
15 & EBA Genel Ağ Sitesinde Yayımlanan Türkçe Soruları & 1 \\
\hline
\end{tabular}

Tablo 3 yorumlandığında toplamda 15 farklı çalışma grubunun / örneklemin yer aldığı görülmektedir. Türkçe eğitimi süreçlerinde bilişim ve teknolojinin kullanımına yönelik yapılan lisansüstü tezlerde en çok seçilen çalışma grubu "ilköğretim 6. sınıf öğrencileri" olmuştur (F:9).

"Öğretmenler" çalışma grubu olarak incelenen lisansüstü tezlerde ikinci olarak en yüksek sayıda seçilmiştir (F:8). Bunların haricinde "lisans öğrencileri" (F:6) çalışma grubu olarak diğer çalışma gruplarına göre daha çok sayıda tercih edilmiştir.

"Yabancı öğrenciler (lisans)" ve "ilköğretim 8. sınıf öğrencileri" çalışma gruplarının incelenen lisansüstü araştırmalarda frekanslarının eşit olduğu görülmüştür (F:4). Buna ek olarak "ilköğretim 5, 6, 7, 8. sınıf öğrencileri" ve "veliler" çalışma gruplarının kullanım frekansları eşittir (F:3). Çalışma grubu olarak incelenen lisansüstü tezlerde "ilköğretim $6,7,8$. sınıf öğrencileri" ve "okul öncesi öğrencileri" daha az başvurulan çalışma grupları olarak göze çarpmaktadır (F:2). "ilköğretim 3. sınıf öğrencileri", "ilköğretim 5. sınıf öğrencileri", "ilkokul öğrencileri” ve "EBA genel ağ sitesinde yayımlanan Türkçe soruları" en az tercih edilen çalışma grupları olmuştur (F:1).

\section{Makalelerin çalışma grupları yönünden incelenmesi}

Türkçe eğitimi süreçlerinde bilişim ve teknolojinin kullanımını inceleyen makaleler kullanılan çalışma grupları yönünden değerlendirilip elde edilen veriler Tablo 4'te sunulmuştur.

Tablo 4.

Makalelerin kullanılan çalışma gruplarına göre dağı̆ımı

\begin{tabular}{lll}
\hline Sıra & Çalışma Grubu & Frekans \\
\hline 1 & Lisans Öğrencileri & 27 \\
2 & Öğretmenler & 8 \\
3 & Mobil Uygulamalar & 3 \\
4 & Yabancı Öğrenciler & 3 \\
5 & 6. Sınıf Öğrencileri & 4 \\
6 & EBA'daki Türkçe Materyalleri & 6
\end{tabular}




$\begin{array}{llr}7 & \text { Türkçe Dersi Öğretim Programı } & 4 \\ 8 & \text { Seçmeli Yazarlık ve Yazma Becerileri Dersi } & 1 \\ 9 & \text { Öğretim Üyeleri } & 1 \\ 10 & \text { Lise Öğrencileri } & 1 \\ 11 & \text { Türkçe Ders Kitapları } & 3\end{array}$

Tablo 4 yorumlandığında toplamda 11 farklı çalışma grubunun yer aldığı görülmektedir. Türkçe eğitimi süreçlerinde bilişim ve teknolojinin kullanımına yönelik yapılan makalelerde en çok tercih edilen çalışma grubu "lisans öğrencileri" olmuştur (F:27).

Öğretmenler" çalışma grubu olarak incelenen makalelerde ikinci olarak en yüksek sayıda tercih edilmiştir ( $F: 8)$. Bu çalışma gruplarından sonra sırasıyla "EBA'daki Türkçe materyallerinin" (F:6), "Türkçe dersi öğretim programı" (F:4) ve "6. sınıf öğrencilerinin" (F:4) geldiği görülmüştür. "Yabancı öğrenciler", "Türkçe ders kitapları" ve "mobil uygulamaların" incelenen makale araştırmalarında çalışma grubu olarak frekansları eşittir (F:3). "Seçmeli yazarlık ve yazma becerileri dersi", "öğretim üyeleri" ve "lise öğrencileri" en az tercih edilen çalışma grupları olmuştur (F:1).

\section{Lisansüstü tezlerin veri toplama araçları yönünden incelenmesi}

Türkçe eğitimi süreçlerinde bilişim ve teknolojinin kullanımını inceleyen lisansüstü tezler kullanılan veri toplama araçları yönünden değerlendirilip elde edilen veriler Tablo 5 'te sunulmuştur.

Tablo 5.

Lisansüstü tezlerin kullanılan veri toplama araçlarına göre dağılımı

\begin{tabular}{|c|c|c|}
\hline Sıra & Konular & Frekans \\
\hline 1 & İnternete Yönelik Epistemolojik İnanç Ölçeği & 1 \\
\hline 2 & Eğitimde Web 2.0 Araçları Kullanım Anketi & 1 \\
\hline 3 & $\begin{array}{l}\text { Teknoloji Kabul ve Kullanımı Birleştirilmiş Modeline Dayalı Web } 2.0 \text { Araçları } \\
\text { Kullanım Ölçeği }\end{array}$ & 1 \\
\hline 4 & Teknoloji Algı Ölçeği & 1 \\
\hline 5 & Başarı Testi & 2 \\
\hline 6 & Sözcükte Anlam Başarı Testi & 1 \\
\hline 7 & Teknopedagojik Eğitim Ölçeği & 1 \\
\hline 8 & Öğretmenlik Özyeterlik Ölçeği & 1 \\
\hline 9 & Dinlemeye Yönelik Tutum ölçeği & 1 \\
\hline 10 & Dinlediğini Anlama Testi & 1 \\
\hline 11 & Çoklu Ortama Dayalı Eleştirel Okuma Testi & 1 \\
\hline 12 & Okuduğunu Anlama Testi & 1 \\
\hline 13 & Değer Farkındalık Testi & 1 \\
\hline 14 & Temel Değerler Ölçeği & 1 \\
\hline 15 & Sözcük Bilgisi Değerlendirme Formu & 1 \\
\hline 16 & Yazma ve Değerlendirme Ölçeği & 2 \\
\hline 17 & Yazma Öz Yeterlikleri Ölçeği (YÖYÖ) & 2 \\
\hline 18 & Okur Öz Yeterlik Ölçeği & 1 \\
\hline 19 & Yanlış Değişim Tablosu & 1 \\
\hline 20 & Kelime Vurgusu Ölçüm Aracı & 1 \\
\hline 21 & Dil Bilgisi Başarı Testi & 1 \\
\hline 22 & Türkçe Dersine Yönelik Tutum Ölçeği & 7 \\
\hline 23 & Açık Uçlu Soru Formu & 1 \\
\hline 24 & Kişisel Bilgi Formu & 12 \\
\hline 25 & Anket & 7 \\
\hline 26 & Bilgisayar Tutum Ölçeği & 4 \\
\hline 27 & Görüşme Formu & 22 \\
\hline
\end{tabular}


Türkçe eğitiminde bilişim ve teknoloji kullanımına yönelik araştırmaların konu alanı ve yöntem yönünden analizi

28 Yapım Ekleri Bilgi Testi 1

29 Türkçe Dersine Yönelik Akademik Başarı Testi 1

30 Kelime Vurgusu Algılama Testi 1

31 Cümle Vurgusu Algılama Testi 1

32 Ton ve Duygu Algılama Testi 1

33 Yazılı Anlatım Derslerine Yönelik Likert Tipi Tutum Ölçeği 1

34 Yazılı Anlatım Akademik Başarı Testi 1

35 Kompozisyon Değerlendirme Ölçeği 1

36 Yazı Yazmaya Yönelik Tutum Ölçeği 1

37 Yazma Öz Yeterliliği Ölçeği 1

38 Yazma Kaygısı Ölçeği $\quad 1$

39 Öykü Yazma Becerileri Dereceli Puanlama Anahtarı 1

40 Metafor Belirleme Formu $\quad 1$

41 Doküman Analizi $\quad 7$

42 Gözlem $\quad 8$

43 Kelime Bilgisi Başarı Testi 2

44 Okuduğunu ve Dinlediğini Anlama Başarı Testleri 2

45 Öğrenci Dosyası $\quad 1$

46 Kitaplar, Süreli Yayınlar ve İnternetten Elde Edilen Haberler 2

47 Film veya Video 3

48 Öğrenci Günlükleri $\quad 2$

49 Ders Planları 1

50 Çizgi Film 2

Tablo 5 yorumlandığında toplamda 50 veri toplama aracının kullanıldı̆̆ı görülmektedir. Türkçe eğitimi süreçlerinde bilişim ve teknolojinin kullanımına yönelik yapılan lisansüstü tezlerde en çok kullanılan veri toplama aracı "görüşme formu" olmuştur (F:22).

"Kişisel bilgi formu" incelenen lisansüstü tezlerde ikinci en çok kullanılan veri toplama aracıdır (F:12). Bunun haricinde sıklıkla kullanılan bir başka veri toplama aracı "gözlem" olmuştur (F:8). "Türkçe dersine yönelik tutum ölçeği" ve "doküman analizinin" incelenen lisansüstü tezlerde veri toplama aracı olarak frekansları eşittir (F:7). Bu bulgulara ek olarak "bilgisayar tutum ölçeği" (F:4) ve "film veya videonun" (F:3) veri toplama aracı olarak daha az kullanıldığı görülmüştür. Sayıca daha az başvurulan veri toplama araçları ise "başarı testi", "yazma değerlendirme ölçeği", "kelime bilgisi başarı testi", "öğrenci günlükleri” vb. şeklinde sıralanabilir (F:2).

Incelenen lisansüstü tezlerden veri toplama aracı olarak en az kullanılanları ise "öğrenci dosyası", "yazma kaygısı ölçeği", "değer farkındalık testi” vb. şeklinde sıralamak mümkündür (F:1). Bütün veri toplama araçları göz önüne alındığında ölçeklerin, başarı testlerinin, formların ve anketlerin geliştirilerek kullanıldığı göze çarpmaktadır.

\section{Makalelerin kullanılan veri toplama araçları yönünden incelenmesi}

Türkçe eğitimi süreçlerinde bilişim ve teknolojinin kullanımını inceleyen makaleler kullanılan veri toplama araçları yönünden değerlendirilip elde edilen veriler Tablo 6' da sunulmuştur.

Tablo 6.

Makalelerin kullanılan veri toplama araçlarına göre dağılımı

\begin{tabular}{lll}
\hline Sıra & Konular & Frekans \\
\hline 1 & Web Sitesi & 10 \\
2 & ilköğretim Türkçe Müfredatı & 1 \\
3 & Bilgisayar Destekli Eğitim Yapmaya İlişkin Tutum Ölçeği & 1 \\
4 & Öğretmen Adaylarının Dijital Pedagojik Yeterlilikleri Ölçeği & 1 \\
5 & Tablet & 1 \\
\hline
\end{tabular}




\begin{tabular}{|c|c|c|}
\hline 6 & $\begin{array}{l}\text { Yabancı Kökenli Bilgisayar ve Genel Ağ Terimlerinin Türkçe Karşılıklarını Bilme } \\
\text { Yeterlik Ölçeği }\end{array}$ & 1 \\
\hline 7 & Eğitim Teknolojisi Standartları Öz Yeterlik Ölçeği & 1 \\
\hline 8 & Kişisel Bilgi Formu & 9 \\
\hline 9 & Yarı Yapılandırmış Görüşme Formu & 18 \\
\hline 10 & Prozodik Okuma Becerisi Ölçeği & 1 \\
\hline 11 & Yazılı Anlatım Becerisi Ölçeği & 1 \\
\hline 12 & Doküman İncelemesi & 9 \\
\hline 13 & Google Form & 2 \\
\hline 14 & Anket & 7 \\
\hline 15 & Yayın Sınıflama Formu & 1 \\
\hline 16 & Türkçe Dersi Başarı Testi & 1 \\
\hline 17 & Türkçe Dersine İlişkin Tutum Ölçeği & 3 \\
\hline 18 & Sosyal Medya & 6 \\
\hline 19 & Okuduğunu Anlama Başarı Testi & 1 \\
\hline 20 & Okuduğunu ve Dinlediğini Anlama Testi & 1 \\
\hline 21 & Kalıcılık Testi & 1 \\
\hline 22 & Teknolojik Pedagojik Alan Bilgisi Ölçeği (Tpab) & 1 \\
\hline 23 & Kavram Haritası Değerlendirme Ölçütleri & 1 \\
\hline 24 & Materyal Tasarlama İlkeleri Ölçütleri & 1 \\
\hline 25 & $\begin{array}{l}\text { Tablet Bilgisayar Destekli Türkçe Öğretiminin Temel Dil Becerilerine Etkisini } \\
\text { Belirlemeye Yönelik Ölçek }\end{array}$ & 1 \\
\hline 26 & Metafor Belirleme Formu & 1 \\
\hline 27 & Teknoloji Tutum Ölçeği & 4 \\
\hline 28 & Türkçe Öğretiminde Bilgi ve Illetişim Teknolojileri Kullanımı Anketi & 1 \\
\hline 29 & Bilgi Teknolojilerini Kullanma Düzeyi Ölçeği & 2 \\
\hline 30 & Başarı Testi & 1 \\
\hline 31 & Web 2.0 Araçları & 2 \\
\hline 32 & Geri Bildirim Bilgi Düzeylerini Belirleme Testi & 1 \\
\hline 33 & Metin Yazma Formu ve Geribildirim Değerlendirme Rubriği & 1 \\
\hline 34 & Konu Bilgi Testi & 1 \\
\hline
\end{tabular}

Tablo 6 yorumlandığında toplamda 34 veri toplama aracının kullanıldığı görülmektedir. Türkçe eğitimi süreçlerinde bilişim ve teknolojinin kullanımına yönelik yapılan makalelerde en çok kullanılan veri toplama aracı "yarı yapılandırmış görüşme formu" olmuştur (F:18). "Web sitesi" incelenen makalelerde ikinci en çok kullanılan veri toplama aracıdır ( $F: 10)$. "Doküman incelemesinin" ve "kişisel bilgi formunun" incelenen makalelerde veri toplama aracı olarak frekansları eşittir ( $F: 9)$. Bunların haricinde "anket" (F:7), "sosyal medya" (F:6) ve "teknoloji tutum ölçeği" (F:4) veri toplama aracı olarak yukarıda sıralanan araçlara göre daha az kullanılmıştır. Incelenen makalelerde sayıca daha az başvurulan veri toplama araçları ise "Web 2.0 araçları", "bilgi teknolojilerini kullanma düzeyi ölçeği" ve "Google form" olmuştur (F:2). Veri toplama aracı olarak incelenen makalelerde en az kullanılanlar ise "konu bilgi testi", "metafor belirleme formu", "yayın sınıflama formu" vb. şeklinde sıralanabilir (F:1). 
Türkçe eğitiminde bilişim ve teknoloji kullanımına yönelik araştırmaların konu alanı ve yöntem yönünden analizi

\section{Lisansüstü tezlerin veri analizi yönünden incelenmesi}

Türkçe eğitimi süreçlerinde bilişim ve teknolojinin kullanımını inceleyen lisansüstü tezler kullanılan veri toplama araçları yönünden değerlendirilip elde edilen veriler Tablo 7'de sunulmuştur.

Tablo 7.

Lisansüstü tezlerin kullanılan veri analiz tekniklerine göre dağılımı

\begin{tabular}{|c|c|c|}
\hline Sira & Veri Analiz Tekniği & Frekans \\
\hline 1 & Basit Korelasyon Analizi & 1 \\
\hline 2 & Çapraz Tablo & 5 \\
\hline 3 & Frekans ve Yüzde & 12 \\
\hline 4 & Shapiro-Wilk & 4 \\
\hline 5 & Mann Whitney U Testi & 13 \\
\hline 6 & Kruskal Wallis $\mathrm{H}$ & 9 \\
\hline 7 & Cronbach's Alpha & 8 \\
\hline 8 & Wilcoxon & 6 \\
\hline 9 & Friedman Test & 1 \\
\hline 10 & T Testi & 14 \\
\hline 11 & Tek Yönlü Varyans Analizi & 8 \\
\hline 12 & Dunnet Post Hoc Testi & 2 \\
\hline 13 & Aritmetik Ortalama & 3 \\
\hline 14 & Standart Sapma & 3 \\
\hline 15 & Sürekli Karşılaştırmalı Analiz Metodu & 1 \\
\hline 16 & Kappa İstatistiği & 1 \\
\hline 17 & KMO ve Barlett & 2 \\
\hline 18 & Faktör Analizi & 3 \\
\hline 19 & Spearman-Brown & 1 \\
\hline 20 & Guttman & 1 \\
\hline 21 & Ancova & 1 \\
\hline 22 & Normallik Testi & 5 \\
\hline 23 & Uç Değer Analizi & 1 \\
\hline 24 & Betimsel Analiz & 3 \\
\hline 25 & İçerik Analizi & 4 \\
\hline 26 & Ki Kare & 3 \\
\hline 27 & İki Yönlü Anova & 2 \\
\hline 28 & Manova & 2 \\
\hline 29 & Bonferroni & 1 \\
\hline 30 & Fisher Exact & 1 \\
\hline 31 & Pearson Momentler Çarpımı Korelasyon Katsayısı & 1 \\
\hline 32 & Sperarman's Rho & 1 \\
\hline 33 & Miles ve Huberman’ın Önerdiği Güvenirlilik Formülü & 4 \\
\hline 34 & Madde Analizi & 3 \\
\hline 35 & Yardımcı Araçlar (SPSS Harici) & 3 \\
\hline 36 & Uzman Görüşü & 1 \\
\hline 37 & Skewness (Çarpıklık) ve Kurtosis (Basıklık) Değerleri & 2 \\
\hline 38 & Tematik Analizi & 1 \\
\hline
\end{tabular}

Tablo 7 yorumlandığında toplamda 38 veri analiz tekniği kullanıldığı görülmektedir. Türkçe eğitimi süreçlerinde bilişim ve teknolojinin kullanımına yönelik yapılan lisansüstü tezlerde en çok kullanılan veri analiz tekniği "T testi" olmuştur (F:14). "Mann Whitney U testi" incelenen lisansüstü tezlerdeki elde edilen verileri analiz etme adına kullanılan en yüksek ikinci teknik olmuştur (F:13). "Frekans ve yüzde" incelenen lisansüstü tezlerde verileri analiz etmede en çok kullanılan tekniklerden 
biri olmuştur ( $F: 12)$. Bu tekniklerden sonra incelenen tezlerde veri analiz tekniklerden "Kruskal Wallis" (F:9) ve "Wilcoxon"un (F:6) kullanıldığı görülmüştür.

Geliştirilen anketlerin güvenirliğini kontrol etmek adına "Cronbach's Alpha" (F:8) ve "KMO ve Barlett" (F:2) kullanılmıştır. "Miles ve Huberman'ın önerdiği güvenirlilik formülü"nün ise 4 çalışmada kullanıldığı tespit edilmiştir.

\section{Makalelerin veri analizi yönünden incelenmesi}

Türkçe eğitimi süreçlerinde bilişim ve teknolojinin kullanımını inceleyen makaleler kullanılan veri toplama araçları yönünden değerlendirilip elde edilen veriler Tablo 8'de sunulmuştur.

Tablo 8.

Makalelerin kullanılan veri analiz tekniklerine göre dağılımı

\begin{tabular}{lll}
\hline Sıra & Veri Analiz Tekniği & Frekans \\
\hline 1 & Bilgisayar Uyarlamalı Test (But) Bileşeni & 1 \\
2 & Frekans Yüzde & 19 \\
3 & Standart Sapma & 3 \\
4 & T Testi & 10 \\
5 & Anova & 7 \\
6 & Scheffe Testi & 1 \\
7 & Shapiro Wilk Testi & 1 \\
8 & Normallik Testi & 2 \\
9 & Mann Whitney U & 4 \\
10 & Kruskal Wallis Testi & 2 \\
11 & Kelime Analizi & 1 \\
12 & Betimsel İstatistiksel Analiz & 2 \\
13 & Aritmetik Ortalama & 5 \\
14 & Betimsel Analiz & 18 \\
15 & İçerik Analizi & 12 \\
16 & Cronbach's Alpha & 5 \\
17 & Miles ve Huberman'ın Önerdiği Güvenirlik Formülü & 4 \\
18 & Uzman Görüşü & 5 \\
19 & Doküman Analizi & 1 \\
20 & F Testi & 2 \\
21 & Tukey Testi & 1 \\
22 & Tek Faktörlü Kovaryans Analizi & 1 \\
\hline
\end{tabular}

Tablo 8 yorumlandığında toplamda 22 veri analiz tekniğinin kullanıldığı görülmektedir. Türkçe eğitimi süreçlerinde bilişim ve teknolojinin kullanımına yönelik yapılan makalelerde en çok kullanılan veri analiz tekniği "Frekans yüzde" olmuştur (F:19). "Betimsel analiz" incelenen makalelerde elde edilen verileri analiz etme adına kullanılan en yüksek ikinci teknik olmuştur (F:18). Bunların haricinde en çok kullanılan teknikler "içerik analizi" (F:12), "t testi" (F:10) ve "anova" (F:7) olmuştur.

"Aritmetik ortalama", "Cronbach's Alpha" ve "uzman görüşünün" incelenen makalelerde veri analiz aracı olarak kullanılma frekansları eşittir (F:5). Aynı zamanda "Mann Whitney U" ve "Miles ve Huberman'ın önerdiği güvenirlik formülünün" kullanılma frekansları eşittir (F:4). "Standart sapma" ise bir betimsel analiz tekniği olarak ortaya çıkmaktadır (F:3).

Sayıca daha az başvurulan veri analiz araçları ise "Kruskal Wallis testi", "F testi", "betimsel istatistiksel analiz" ve "normallik testi" olmuştur (F:2). Veri toplama aracı olarak incelenen makalelerde en az kullanılanlar ise "kelime analizi", "Shapiro Wilk testi", "Scheffe testi" vb. şeklinde sıralanabilir ( $F: 1)$. 
Türkçe eğitiminde bilişim ve teknoloji kullanımına yönelik araştırmaların konu alanı ve yöntem yönünden analizi

\section{Sonuç ve Tartışma}

$\mathrm{Bu}$ araştırma kapsamında incelenen tezlerde toplamda 19 konu alanının yer aldığı görülmektedir. Türkçe eğitimi süreçlerinde bilişim ve teknolojinin kullanımına yönelik yapılan lisansüstü tezlerde en çok araştırılan konu alanı "çoklu ortam-dil becerileri etkileşimi” olmuştur (F:9). Bu tezlerden 6'sı doktora tezi, 3'ü ise yüksek lisans tezidir. "Yabancılara Türkçe öğretim süreçlerinde e-içerik kullanımı" (F:7) ve "e-içerik-dil becerilerinin etkileşimi" (F:7) konu alanları ise diğer yüksek frekansa sahip olan alanlardır. Araştırma kapsamında incelenen makalelerde ise toplamda 23 konu alanının yer aldığı görülmektedir. Türkçe eğitimi süreçlerinde bilişim ve teknolojinin kullanımına yönelik yapılan makalelerde en çok araştırılan konuların "yabancılara Türkçe öğretim süreçlerinde eiçerik, teknoloji kullanımı" ve "teknoloji, bilgisayar destekli Türkçe eğitimi” olduğu görülmektedir (F:11). "Öğretmen adaylarının derslerde teknoloji, çoklu ortam kullanımına yönelik görüşleri" (F:9) ve "EBA'ya yönelik analiz" (F:8) konu alanları diğer yüksek frekansa sahip olan alanlardır.

Araştırma kapsamında incelenen tezlerde toplamda 20 araştırma modelinin yer aldığı görülmektedir. Türkçe eğitimi süreçlerinde bilişim ve teknolojinin kullanımına yönelik yapılan lisansüstü tezlerde en çok kullanılan araştırma modeli "ön test-son test kontrol gruplu deneysel desen" olmuştur (F:17). "Karma yöntem" (F:11), "tarama modeli"(F:4) ve "betimsel tarama modeli" (F:5) diğer araştırma modelleri arasında yüksek frekansa sahip olan modellerdir. Araştırma kapsamında incelenen makalelerde ise toplamda 14 araştırma modelinin yer aldığı görülmektedir. Türkçe eğitimi süreçlerinde bilişim ve teknolojinin kullanımına yönelik yapılan makalelerde en çok kullanılan araştırma modeli "literatür tarama" olmuştur (F:21). "Tarama modeli" (F:15), "nitel araştırma" (F:13) ve "betimsel tarama modelinin" (F:8) de incelenen makalelerde yüksek oranda kullanıldığı görülmüştür.

Araştırma kapsamında incelenen tezlerde toplamda 15 çalışma grubunun yer aldığı tespit edilmiştir. Türkçe eğitimi süreçlerinde bilişim ve teknolojinin kullanımına yönelik yapılan lisansüstü tezlerde en çok tercih edilen çalışma grubunun "ilköğretim 6. sınıf öğrencileri” olduğu görülmüştür (F:9). "Öğretmenler" (F:8), "lisans öğrencileri" (F:6), "yabancı öğrenciler (lisans)" (F:4) ve "ilköğretim 8. sınıf öğrencileri" (F:4) çalışma grubu olarak yüksek frekansa sahip diğer çalışma gruplarıdır. Araştırma kapsamında incelenen makalelerde ise toplamda 11 çalışma grubunun yer aldığı görülmektedir. Türkçe eğitimi süreçlerinde bilişim ve teknolojinin kullanımına yönelik yapılan makalelerde en çok tercih edilen çalışma grubu "lisans öğrencileri" olmuştur (F:27). "Öğretmenler" (F:8) ve "EBA'daki Türkçe materyalleri" (F:6) yüksek frekansa sahip olan diğer (örneklem) çalışma grubudur.

Araştırma kapsamında incelenen tezlerde toplamda 50 veri toplama aracının yer aldığı görülmektedir. Türkçe eğitimi süreçlerinde bilişim ve teknolojinin kullanımına yönelik yapılan lisansüstü tezlerde en çok kullanılan veri toplama aracı "görüşme formu" olmuştur (F:22). "Kişisel bilgi formu" (F:12), "gözlem" (F:8), "Türkçe dersine yönelik tutum ölçeği" (F:7) ve "doküman analizi" (F:7) diğer yüksek frekansa sahip olan veri toplama araçlarıdır. Araştırma kapsamında incelenen makalelerde ise toplamda 34 veri toplama aracı yer almaktadır. Türkçe eğitimi süreçlerinde bilişim ve teknolojinin kullanımına yönelik yapılan makalelerde en çok kullanılan veri toplama aracı "yarı yapılandırmış görüşme formu" olmuştur (F:18). "Web sitesi" (F:10), "doküman incelemesi" (F:9) ve "kişisel bilgi formu" (F:9) veri toplama aracı olarak yüksek frekansa sahip diğer alanlardır.

Araştırma kapsamında incelenen makalelerde toplamda 38 veri analizi tekniği kullanıldığı görülmektedir. Türkçe eğitimi süreçlerinde bilişim ve teknolojinin kullanımına yönelik yapılan lisansüstü tezlerde en çok kullanılan veri analiz tekniği "T testi" olmuştur (F:14). "Mann Whitney U testi" (F:13), "frekans ve yüzde" (F:12), "Kruskal Wallis H" (F:9) ve "Wilcoxon" (F:6) diğer yüksek frekansa sahip veri analizi teknikleridir. Araştırma kapsamında incelenen makalelerde ise toplamda 22 veri analizi tekniği kullandığı görülmektedir. Türkçe eğitimi süreçlerinde bilişim ve teknolojinin kullanımına yönelik yapılan makalelerde en çok kullanılan veri analizi tekniği "frekans yüzde" olmuştur (F:19). "Betimsel analiz" (F:18), "içerik analizi" (F:12) ve "t testi" (F:10) de veri analizi tekniği olarak yüksek frekansa sahiptir.

Bu araştırma sonuçlarına göre Türkçe derslerinde bilişim ve teknolojinin kullanımına yönelik araştırmaların konu alanı, yöntem, teknik gibi başlıklar yönünden çeşitlilik gösterdiği görülmüştür. Bu 
durum Türkçe eğitimi ve bilişim teknolojileri alanlarının uygulama açısından iş birliğini göstermesi yönünden önemlidir. Nitekim Türkçe eğitimi alanının disiplinler arası yönüyle ilgili olarak Özçakmak (2017: 1615), araştırmasında Türkçe eğitimi alanında yapılan lisansüstü tezlerde özellikle disiplinler arası duruma dikkat çeker ve Türkçe eğitimi alanına disiplinler arası bir ilginin olduğunu belirtir.

Araştırmada tezlerin ve makalelerin konu alanları incelendiğinde yabancılara Türkçe eğitiminde bilişim ve teknoloji kullanımı konusunda birçok çalışmanın olduğu görülmektedir. Bu durum yabancılara Türkçe eğitimi alanına ilginin olduğunu göstermektedir. Nitekim bu duruma araştırmasında Türkben (2018: 2774) de değinir ve yıllar içerisinde bu alanla ilgili çalışmaların sayısında artışın olduğu ifade eder.

Varışoğlu, Şahin ve Göktaş (2013: 1767) 2000-2011 yılları aralığında Türkçe eğitimi alanında yayımlanan makaleleri inceledikleri çalışmalarında araştırma modeli olarak tarama modelinin, analiz yöntemleri arasında da betimsel analizin ön plana çıktığını belirtirmişlerdir. İlgili sonuçlarla benzer olarak bu araştırmada da makalelerde kullanılan model ve analiz yöntemleri arasında tarama modellerinin ve betimsel analiz yöntemlerinin önemli oranda olduğu görülmektedir. Bu duruma değinen Büyükikiz (2014: 212) yabancılara Türkçe eğitimi alanında yapılan lisansüstü tezlerin genelde betimsel çalışmalar olduğunu ve deneysel çalışmaların oransal açıdan daha az olduğunu belirterek konuya eleştirel bir bakış açısıyla yaklaşmıştır.

\section{Kaynaklar}

Akçay, A., Özcan, M. F. (2012). Türkçe öğretmeni adaylarının bilgisayar ve genel ağ terimlerinin Türkçe karşılıklarını bilme yeterlikleri. Uluslararası Türkçe Edebiyat Kültür Eğitim (Teke) Dergisi, 1(4), 151-161.

Akın, E. (2015). Türkçe öğretmenlerinin kaynaştırma öğrencilerinin eğitiminde çoklu ortam araçlarından faydalanmaya yönelik görüşlerinin incelenmesi. Eğitim ve Öğretim Araştırmaları Dergisi, 4(4), 384-393.

Aktay, S., Keskin, T. (2016). Eğitim bilişim ağı incelemesi. Eğitim Kuram ve Uygulama Araştırma Dergisi, 2(3), 27-44.

Arıcl, N., Karacı, A. (2013). Türkçe öğrenimi için web tabanlı zeki öğretim sistemi (Türkzös) ve değerlendirmesi. Electronic Turkish Studies, 8(8), 65-87.

Banguoğlu, T. (2015). Türkçenin grameri. Ankara: Türk Dil Kurumu Yayınları.

Bayburtlu, Y. S. (2019). Sosyal ağlar-sanal eğitim ortamlarının Türkçe eğitimine ve öğrencilerin kelime hazinelerine katkılarına dair öğretmen görüşleri. Researcher: Social Science Studies, 7(4), 373385.

Bayburtlu, Y.S. (2020). Covid-19 pandemi dönemi uzaktan eğitim sürecinde öğretmen görüşlerine göre Türkçe eğitimi. Turkish Studies, 15(4), 131-151.

Becel, A. (2014). Yabancılara Türkçe öğretimi iç̧in geliştirilen müzikal beyin eğitmeni: Earworm (s). Eğitim ve Öğretim Araştırmaları Dergisi, 3(3), 99-106.

Büyükikiz, K. K. (2014). Yabancılara Türkçe öğretimi alanında hazırlanan lisansüstü tezler üzerine bir inceleme. Mustafa Kemal Üniversitesi Sosyal Bilimler Enstitüsü Dergisi, 11(25), 203-213.

Can, E., Topçuoğlu Ünal, F. (2018). Eğitim Bilişim Ağı kullanımının (EBA) ortaokul öğrencilerinin Türkçe dersine yönelik tutumlarına etkisi. Eskişehir Osmangazi Üniversitesi Türk Dünyası Uygulama ve Araştırma Merkezi Eğitim Dergisi, 3(1), 61-68.

Candeğer, Ü., Mete, F., Büyükköse, Ş. (2017). Millî Eğitim Bakanlığı Eğitim Bilişim Ağı'nda bulunan kavram haritalarının incelenmesi. E-Kafkas Eğitim Araştırmaları Dergisi, 4(1), 11-25.

Göçer, A. (2018). Metin işleme süreçli- mikro öğretim uygulama örnekli- Türkçe öğrenme ve öğretim yaklaşımları. Ankara: Pegem Akademi.

İskender, H. (2016). Eğitim Bilişim Ağı'nda bulunan 7. sınıf Türkçe dersi videolarının ilköğretim Türkçe dersi $(6,7,8$. sınıflar) öğretim programıyla uyumu. Adıyaman Üniversitesi Sosyal Bilimler Enstitüsü Dergisi, 8(24), 1043-1068.

İskender, M. E., Gücüyeter, B. (2019). Yabancı dil olarak Türkçe yazma öğretiminde anlık mesajlaşma programlarının kullanımı: Whatsapp uygulaması örneği. Sosyal Bilimler Araştırmaları Dergisi, 14(2), 571-590. 
Türkçe eğitiminde bilişim ve teknoloji kullanımına yönelik araştırmaların konu alanı ve yöntem yönünden analizi

Maden, A. (2019). Türkçe öğretmeni adaylarının mobil iletişim alışkanlıkları: Whatsapp örneği. Elektronik Sosyal Bilimler Dergisi, 18(72), 1797-1811.

MEB. (2019). Türkçe dersi öğretim programı. MEB Yayınları.

Sever, S. (2011). Türkçe öğretimi ve tam öğrenme. Ankara: Anı Yayıncılık.

Şahin, A., Akçay, A. (2011). Türkçe öğretmeni adaylarının bilgisayar destekli eğitime ilişkin tutumlarının incelenmesi. Electronic Turkish Studies, 6(2), 909-918.

Özçakmak, H. (2017). Türkçe eğitimi lisansüstü araştırmalarında yeni yönelimler (2011-2015). Uluslararası Türkçe Edebiyat Kültür Eğitim Dergisi, 6(3), 1607-1618.

TDK (2020). Bilişim. 20.08.2020 tarihinde https://sozluk.gov.tr/ adresinden erişildi.

Timur, B., Yılmaz, Ş., İşseven, A. (2017). Ortaokul öğrencilerinin Eğitim Bilişim Ağı (EBA) sistemini kullanmalarına yönelik görüşleri. Asian Journal of Instruction, 5(1), 44-54.

Türkben, T. (2018). Yabancı dil olarak Türkçe öğretimi alanında yapılan lisansüstü çalışmaların değerlendirilmesi. Uluslararası Türkçe Edebiyat Kültür Eğitim Dergisi, 7(4), 2464-2479.

Türker, M. S. (2019). Yabancı dil olarak Türkçe öğretenlerin eğitim teknolojisi standartları öz-yeterlik algılarının incelenmesi. Ana Dili Eğitimi Dergisi, 7(3), 574-596.

Varışoğlu, B., Şahin, A., Göktaş, Y. (2013). Türkçe eğitimi araştırmalarında eğilimler. Kuram ve Uygulamada Ĕgitim Bilimleri, 13(3), 1767-1781.

Yaman, H. (2007). Türkçe öğretmeni adaylarının "öğretim teknolojileri ve materyal geliştirme" dersi bağlamında Türkçe öğretiminde teknoloji kullanımına ilişkin yeterlilik ve algıları. Hayef Journal of Education, 4(1), 57-71.

Yaman, H., Demirtaş, T., Aydemir, Z. İ. (2013). Türkçe öğretmeni adaylarının dijital pedagojik yeterlilikleri. Electronic Turkish Studies, 8(8), 1407-1419.

Yavuz, S., Çoşkun, E. (2008). Sınıf öğretmenliği öğrencilerinin eğitimde teknoloji kullanımına ilişkin tutum ve düşünceleri. Hacettepe Üniversitesi Eğitim Fakültesi Dergisi (H. U. Journal of Education) 34, 276-286.

Yıldırım, A. Şimşek, H. (2008). Sosyal bilimlerde nitel araştırma yöntemleri. Ankara: Seçkin Yayıncılık.

\section{Introduction}

\section{Extended Abstract}

Research on the use of information and technology in the field of Turkish education has been increasing, especially recently. In this research, it is observed that the effectiveness of designed web programs, the availability of multimedia in courses, the impact of information and communication tools on language skills, teacher and student competencies, etc. Arıcl and Karacı (2013: 86) investigated the effectiveness of an internet-based application in Turkish education developed in their research and stated that the application could be used in both the native language and teaching Turkish to foreigners.

Studies show that there are studies especially for teacher candidates. Şahin and Akçay (2011: 909) state that teacher candidates' attitudes towards computer-aided teaching have increased in the same direction with the subject of computer-aided teaching of Turkish lessons. Yaman, Demirtaş, Aydemir (2013: 1407) found in their research that teacher candidates who are competent in using information technologies are also competent in terms of "digital pedagogy". Akçay and Özcan (2012: 151) state in their research that Turkish teacher candidates are not sufficient to know the Turkish equivalents of foreign words in informatics.

\section{Method}

The purpose of this research, in which the scanning model is used, is the analysis of the researches on the use of information technologies in Turkish language teaching processes. In this direction, postgraduate theses and articles related to the subject area were examined. The questions to be answered in this research are as follows:

1. In what subject areas are the research conducted on the use of information technologies in Turkish lesson teaching processes? 
2. What are the methodological features of the researches about the utilization of information technologies in Turkish lesson teaching processes?

The sample of this research is the research on the use of information technologies in Turkish teaching processes. These researches are classified as postgraduate theses and articles. Document analysis method was used to reach the data. Content analysis method was used in this research. Postgraduate theses and articles were classified in terms of subject areas in the research. In the classification of these studies in terms of subject areas, tables were used to express the data in a simpler way. Then, frequency values were calculated in terms of subject areas of the studied studies. This has contributed to determining which subject areas the studies are grouped in and determining which areas there are more and less studies using frequency values.

\section{Result and Discussion}

In general, the research results are summarized in theses in terms of the subject area of multimedia - language skills interaction and the use of e-content in Turkish teaching processes for foreigners and the interaction of e-content - language skills, etc. In the articles, it has been determined that the titles of e-content, use of technology and technology, computer-aided Turkish education have come to the fore in the processes of teaching Turkish to foreigners. It was observed that the experimental design with pre-test and post-test control group in post-graduate theses, and scanning models in articles were the most used research models.

According to the results of this research, research on the use of information and technology in Turkish courses has varied in terms of topics such as subject area, method, technique. This situation is important in terms of showing cooperation in terms of Turkish education and information technology fields. As a matter of fact, regarding the interdisciplinary aspect of the field of Turkish education, Özçakmak (2017: 1615) especially draws attention to the interdisciplinary situation in the graduate theses in the field of Turkish education and states that there is an interdisciplinary interest in the field of Turkish education.

In the research, when the subject areas of theses and articles are examined, it is seen that there are many studies on the use of information and technology in Turkish education for foreigners. This indicates an interest in the field of Turkish education for foreigners. As a matter of fact, Türkben (2018:2774) also refers to this situation in his research and states that there has been an increase in the number of studies related to this field over the years.

Varışoğlu, Şahin and Göktaş (2013:1767) in their study of the articles published in the field of Turkish education in the period 2000-2011, they stated that the screening model as a research model and descriptive analysis came to the fore among the analysis methods. Similar to the related results, it is seen that scanning models and descriptive analysis methods are important among the models and analysis methods used in the articles in this study. Referring to this situation, Büyükikiz (2014: 212) approaches the subject with a critical point of view, stating that the postgraduate theses in the field of Turkish education for foreigners are generally descriptive studies and that experimental studies are proportionally less.

\section{Ekler}

\section{Ek-1. İncelenen tezlerin kaynakçası}

\begin{tabular}{|c|l|}
\hline 1. & $\begin{array}{l}\text { Akçay, A. (2009). Webquest (web macerası) öğretim yönteminin Türkçe dersindeki } \\
\text { akademik başarı ve tutuma etkisi. (Yayımlanmamış yüksek lisans tezi). Atatürk } \\
\text { Üniversitesi Sosyal Bilimler Enstitüsü, Erzurum. }\end{array}$ \\
\hline 2. & $\begin{array}{l}\text { Akgün, M. A. (2020). Türkçe öğretmeni adaylarının internete yönelik epistemolojik } \\
\text { inançlarının araştırılması. (Yayımlanmamış yüksek lisans tezi). Çanakkale Onsekiz Mart } \\
\text { Üniversitesi Eğitim Bilimleri Enstitüsü, Çanakkale. }\end{array}$ \\
\hline 3. & $\begin{array}{l}\text { Akın, E. (2015). Çoklu ortam uygulamalarına dayalı öğretimin 6. sınıf öğrencilerinin } \\
\text { anlama becerilerine ve Türkçe dersi tutumlarına etkisi (Muş ili örneği). (Yayımlanmamış } \\
\text { doktora tezi). Inönü Üniversitesi Eğitim Bilimleri Enstitüsü, Malatya. }\end{array}$ \\
\hline
\end{tabular}


Türkçe eğitiminde bilişim ve teknoloji kullanımına yönelik araştırmaların konu alanı ve yöntem yönünden analizi

\begin{tabular}{|c|c|}
\hline 4. & $\begin{array}{l}\text { evli, O. (2014). Ekrandan okumanın 8. sınıf öğrencilerinde anlamaya etkisi. } \\
\text { ayımlanmamış yüksek lisans tezi). Uşak Üniversitesi Sosyal Bilimler Enstitüsü, Uşak. }\end{array}$ \\
\hline 5. & $\begin{array}{l}\text { Avcı, S. (2012). İlköğretim 6. sınıf Türkçe dersinde yapım ekleri öğretiminde reklam } \\
\text { filmlerinin kullanımı. (Yayımlanmamış yüksek lisans tezi). Sakarya Üniversitesi Eğitim } \\
\text { Bilimleri Enstitüsü, Sakarya. }\end{array}$ \\
\hline 6. & $\begin{array}{l}\text { Baki, Y. (2015). Dijital öykülerin altıncı sınıf öğrencilerinin yazma sürecine etkisi. } \\
\text { (Yayımlanmamış doktora tezi). Atatürk Üniversitesi Eğitim Bilimleri Enstitüsü, Erzurum. }\end{array}$ \\
\hline 7. & $\begin{array}{l}\text { Buldu, E. B. (2018). Alt yazılı ve alt yazısız televizyon programlarının yabancı öğrencilerin } \\
\text { dinleme/izleme ve anlama becerileri üzerindeki etkisi. Sakarya Üniversitesi Eğitim } \\
\text { Bilimleri Enstitüsü, Sakarya. }\end{array}$ \\
\hline 8. & $\begin{array}{l}\text { Bursalı, H. (2014). Çizgi dizilerin beşinci ve altıncı sınıf öğrencilerinin söz varlığına katkısı. } \\
\text { (Yayımlanmamış yüksek lisans tezi). Dumlupınar Üniversitesi Eğitim Bilimleri Enstitüsü, } \\
\text { Kütahya. }\end{array}$ \\
\hline 9. & $\begin{array}{l}\text { Cayhan, C. (2017). Ortaokul öğrencilerinin Wattpad uygulaması kullanımı ile okuma ve } \\
\text { yazma öz yeterlikleri arasındaki ilişkinin incelenmesi. (Yayımlanmamış yüksek lisans } \\
\text { tezi). Siirt Üniversitesi Sosyal Bilimler Enstitüsü, Siirt. }\end{array}$ \\
\hline 10. & $\begin{array}{l}\text { Ceylan, M. (2017). Bilgisayarda yazma çalışmaları sonrasında verilen geri bildirimin } \\
\text { dördüncü sınıf öğrencilerinin yazma becerilerine etkisi. (Yayımlanmamış yüksek lisans } \\
\text { tezi). Gazi Üniversitesi Eğitim Bilimleri Enstitüsü, Ankara. }\end{array}$ \\
\hline 11. & $\begin{array}{l}\text { Çetin, D. (2013). Bilgisayar destekli prozodi eğitiminin vurgu, ton ve duyguyu algılama } \\
\text { ve yansıtma becerilerine etkisi. (Yayımlanmamış doktora tezi). Gazi Üniversitesi Eğitim } \\
\text { Bilimleri Enstitüsü, Ankara. }\end{array}$ \\
\hline 12. & $\begin{array}{l}\text { Delen, M. (2016). Yabancılara Türkçe öğretiminde filmlerin kullanımı (Selvi boylum al } \\
\text { yazmalım filmi örneği). (Yayımlanmamış yüksek lisans tezi). Gaziosmanpaşa Üniversitesi } \\
\text { Eğitim Bilimleri Enstitüsü, Tokat. }\end{array}$ \\
\hline 13. & $\begin{array}{l}\text { Demir, A. (2019). Türkçe öğretmeni adaylarının geri bildirimlerinde teknoloji destekli } \\
\text { öğretim ile geleneksel öğretim yönteminin etkisi. (Yayımlanmamış yüksek lisans tezi). } \\
\text { Hatay Mustafa Kemal Üniversitesi Sosyal Bilimler Enstitüsü, Hatay. }\end{array}$ \\
\hline 14. & $\begin{array}{l}\text { Durukan, E. (2011). Illköğretim 6. sınıfta bilgisayar destekli dil bilgisi öğretiminin başarı } \\
\text { ve tutuma etkisi. (Yayımlanmamış doktora tezi). Atatürk Üniversitesi Eğitim Bilimleri } \\
\text { Enstitüsü, Erzurum. }\end{array}$ \\
\hline 15. & $\begin{array}{l}\text { Elkıran, Y. M. (2019). Türkçe öğretmeni adaylarının teknoloji entegrasyonu yeterlikleri } \\
\text { ile öğretmenlik özyeterlikleri arasındaki ilişki. (Yayımlanmamış doktora tezi). Çanakkale } \\
\text { Onsekiz Mart Üniversitesi Eğitim Bilimleri Enstitüsü, Çanakkale. }\end{array}$ \\
\hline 16. & $\begin{array}{l}\text { Göçen, G. (2011). Televizyonun konuşma eğitimine etkileri. (Yayımlanmamış yüksek } \\
\text { lisans tezi). Sakarya Üniversitesi Eğitim Bilimleri Enstitüsü, Sakarya. }\end{array}$ \\
\hline 17. & $\begin{array}{l}\text { Gülcü, i. (2015). Yabancı dil olarak mobil destekli Türkçe kelime öğretimi. } \\
\text { (Yayımlanmamış doktora tezi). Çanakkale Onsekiz Mart Üniversitesi Eğitim Bilimleri } \\
\text { Enstitüsü, Çanakkale. }\end{array}$ \\
\hline 18. & $\begin{array}{l}\text { İnalöz, A. B. (2016). Ortaokul 8. sınıf öğrencilerinin Türkçe dersinde kullandıkları dil ile } \\
\text { sosyal medya ortamında kullandıkları dilin karşılaştırılması: Facebook örneği. } \\
\text { (Yayımlanmamış yüksek lisans tezi). Başkent Üniversitesi Eğitim Bilimleri Enstitüsü. } \\
\text { Ankara. }\end{array}$ \\
\hline 19. & $\begin{array}{l}\text { İnce, V. (2018). Eğitim Bilişim Ağında (EBA) yer alan soruların Türkçe öğretim } \\
\text { programıyla karşılaştırılması. (Yayımlanmamış yüksek lisans tezi). Fırat Üniversitesi } \\
\text { Eğitim Bilimleri Enstitüsü, Elazığ. }\end{array}$ \\
\hline 20. & $\begin{array}{l}\text { Kaplan, K. (2017). Medya okuryazarlığı dersinin Türkçe öğretimiyle birleştirilmesi } \\
\text { sürecinde medya okuryazarlığı dersi öğretmenlerinde bulunması gereken yeterlikler. } \\
\text { (Yayımlanmamış doktora tezi). Gazi Üniversitesi Eğitim Bilimleri Enstitüsü, Ankara. }\end{array}$ \\
\hline 21. & Karacaoğlu, H. (2018). Dijital hikâyelerin Türkçe dersi değerler eğitimine yc \\
\hline
\end{tabular}




\begin{tabular}{|c|c|}
\hline & $\begin{array}{l}\text { etkisinin incelenmesi. (Yayımlanmamış yüksek lisans tezi). Erciyes Üniversitesi Eğitim } \\
\text { Bilimleri Enstitüsü, Kayseri. }\end{array}$ \\
\hline 22. & $\begin{array}{l}\text { Karaosmanoğlu, P. (2019). Wattpad kitapları üzerine bir içerik çözümlemesi. } \\
\text { (Yayımlanmamış yüksek lisans tezi). Trabzon Üniversitesi Lisansüstü Eğitim Enstitüsü, } \\
\text { Trabzon. }\end{array}$ \\
\hline 23. & $\begin{array}{l}\text { Kır, D. B. (2019). Çoklu ortam destekli dinleme metinlerinin dinleme becerisine etkisi. } \\
\text { (Yayımlanmamış yüksek lisans tezi). Yıldız Teknik Üniversitesi Sosyal Bilimler Enstitüsü, } \\
\text { İstanbul. }\end{array}$ \\
\hline 24. & $\begin{array}{l}\text { Kırmacı, Ö. (2015). Ortaokul öğrencilerinin kitap okuma etkinliklerinin çevrim içi takip ve } \\
\text { değerlendirme sisteminin geliştirilmesi. (Yayımlanmamış yüksek lisans tezi). Çanakkale } \\
\text { Onsekiz Mart Üniversitesi Eğitim Bilimleri Enstitüsü, Çanakkale. }\end{array}$ \\
\hline 25. & $\begin{array}{l}\text { Kurt, E. (2014). TRT çocuk kanalının 4-6 yaş grubu öğrencilerinin dil gelişimine etkisi } \\
\text { hakkında öğrenci, öğretmen ve veli görüşleri. (Yayımlanmamış yüksek lisans tezi). } \\
\text { Karadeniz Teknik Üniversitesi Eğitim Bilimleri Enstitüsü, Trabzon. }\end{array}$ \\
\hline 26. & $\begin{array}{l}\text { Maden, A. (2019). Ortaokul öğrencilerine yönelik elektronik görsel sözlük geliştirme: } \\
\text { tasarım tabanlı bir araştırma (5. sınıf örneği). (Yayımlanmamış doktora tezi). Trabzon } \\
\text { Üniversitesi Lisansüstü Eğitim Enstitüsü, Trabzon. }\end{array}$ \\
\hline 27. & $\begin{array}{l}\text { Opuş, M. Y. (2019). Türkçe öğretmenlerinin sosyal medyadaki dil kullanımının yazım } \\
\text { (imla) açısından incelenmesi: Facebook örneği. (Yayımlanmamış yüksek lisans tezi). } \\
\text { Kütahya Dumlupınar Üniversitesi Eğitim Bilimleri Enstitüsü, Kütahya. }\end{array}$ \\
\hline 28. & $\begin{array}{l}\text { Ovalı, T. (2011). İlköğretim sekizinci sınıf Türkçe dersinde bilgisayar destekli öğretimin } \\
\text { öğrencilerin anlama becerisine etkisi. (Yayımlanmamış yüksek lisans tezi). Sakarya } \\
\text { Üniversitesi Eğitim Bilimleri Enstitüsü, Sakarya. }\end{array}$ \\
\hline 29. & $\begin{array}{l}\text { Özbal, A. (2017). Yazma becerisinin geliştirilmesinde WEB } 2.0 \text { araçlarının kullanılması. } \\
\text { (Yayımlanmamış yüksek lisans tezi). Akdeniz Üniversitesi Eğitim Bilimleri Enstitüsü, } \\
\text { Antalya. }\end{array}$ \\
\hline 30. & $\begin{array}{l}\text { Özipek, K. (2019). Padlet uygulamasının öğrencilerin akademik başarıları ile teknolojiye } \\
\text { ve Türkçe dersine karşı tutumlarına etkisi. (Yayımlanmamış yüksek lisans tezi). Marmara } \\
\text { Üniversitesi Eğitim Bilimleri Enstitüsü, İstanbul. }\end{array}$ \\
\hline 31. & $\begin{array}{l}\text { Özonat, Z. (2018). Çoklu ortama dayalı eleştirel okuma eğitiminin 6. sınıf öğrencilerinin } \\
\text { eleştirel okuma becerilerine etkisi. (Yayımlanmamış doktora tezi). İnönü Üniversitesi } \\
\text { Eğitim Bilimleri Enstitüsü. Malatya. }\end{array}$ \\
\hline 32. & $\begin{array}{l}\text { Peker, B. (2018). Multimedya araçlarının yabancı dil öğretimine etkisi üzerine öğretmen } \\
\text { görüşleri. Yayımlanmamış yüksek lisans tezi). Çanakkale Onsekiz Mart Üniversitesi } \\
\text { Eğitim Bilimleri Enstitüsü, Çanakkale. }\end{array}$ \\
\hline 33. & $\begin{array}{l}\text { Sarıman, G. (2016). Yabancı dil olarak Türkçe öğretiminde bilgisayar destekli eğitimin } \\
\text { kelime vurgulama becerisine etkisi. (Yayımlanmamış yüksek lisans tezi). Muğla Sıtkı } \\
\text { Koçman Üniversitesi Eğitim Bilimleri Enstitüsü, Muğla. }\end{array}$ \\
\hline 34. & $\begin{array}{l}\text { Sayın, H. (2015). Medya okuryazarlığı becerilerinin ortaokul Türkçe programı } \\
\text { içerisindeki yeri ve öğrencilerin medya metinleri üretme becerilerinin değerlendirilmesi. } \\
\text { (Yayımlanmamış yüksek lisans tezi). Erciyes Üniversitesi Eğitim Bilimleri Enstitüsü, } \\
\text { Kayseri. }\end{array}$ \\
\hline 35. & $\begin{array}{l}\text { Şahin, R. N. (2019). TRT’nin çocuklara yönelik çizgi filmlerinin Türkçe öğretimi ve değer } \\
\text { aktarımı açısından incelenmesi. (Yayımlanmamış doktora tezi). Gazi Üniversitesi Eğitim } \\
\text { Bilimleri Enstitüsü, Ankara. }\end{array}$ \\
\hline 36. & $\begin{array}{l}\text { Şanal, A. (2016). Ders kitabı olarak z-kitap kullanımının okuduğunu anlamaya etkisi. } \\
\text { (Yayımlanmamış yüksek lisans tezi). Abant İzzet Baysal Üniversitesi Eğitim Bilimleri } \\
\text { Enstitüsü, Bolu. }\end{array}$ \\
\hline 37. & $\begin{array}{l}\text { Şener, F. (2019). Teknopedagojik eğitim kapsamında Türkçe öğretmenlerinin Web } 2.0 \\
\text { araçlarını kullanma durumları. (Yayımlanmamış yüksek lisans tezi). Çanakkale Onsekiz }\end{array}$ \\
\hline
\end{tabular}


Türkçe eğitiminde bilişim ve teknoloji kullanımına yönelik araştırmaların konu alanı ve yöntem yönünden analizi

\begin{tabular}{|c|l|}
\hline 38. & Mart Üniversitesi Eğitim Bilimleri Enstitüsü, Çanakkale. \\
\hline 39. & $\begin{array}{l}\text { Şimşek, B. (2018). Çevrim içi oyunların Türkçenin söz varlığına etkisinin incelenmesi. } \\
\text { (Yayımlanmamış yüksek lisans tezi). Akdeniz Üniversitesi Eğitim Bilimleri Enstitüsü, } \\
\text { Antalya. }\end{array}$ \\
\hline 40. & $\begin{array}{l}\text { Tıraşoğlu, C. (2019). Yabancılara Türkçe öğretiminde söz varlığını geliştirmeye yönelik } \\
\text { Ueb 2.0 araçları: Kahoot! Örneği. (Yayımlanmamış yüksek lisans tezi). Akdeniz } \\
\text { Üniversitesi Eğitim Bilimleri Enstitüsü, Antalya. }\end{array}$ \\
\hline 41. & $\begin{array}{l}\text { Turhan, H. (2016). Çok uyaranlı eğitim ortamlarının öğrencilerin okuduğunu anlama ve } \\
\text { yazılı anlatım becerilerine etkisi. (Yayımlanmamış doktora tezi). Ankara Üniversitesi }\end{array}$ \\
\hline 42. & $\begin{array}{l}\text { Türker, F. M. (2014). Web tabanlı uzaktan Türkçe öğretimi uygulamalarının yazılı } \\
\text { anlatım dersinde başarı ve tutuma etkisi. (Yayımlanmamış doktora tezi). Çanakkale } \\
\text { Onsekiz Mart Üniversitesi Eğitim Bilimleri Enstitüsü, Çanakkale. }\end{array}$ \\
\hline $\begin{array}{l}\text { Uçar, T. (2019). Taşınabilir cihazlar aracıllı̆ıyla yabancı dil olarak Türkçe öğrenimi } \\
\text { uygulamalarının belirlenmesi, sınıflandırılması ve öğrenci kazanımlarına ilişkin öğrenci } \\
\text { değerlendirmeleri. (Yayımlanmamış yüksek lisans tezi). Bursa Uludağ Üniversitesi Eğitim } \\
\text { Bilimleri Enstitüsü, Bursa. }\end{array}$ \\
\hline 43. & $\begin{array}{l}\text { Ulu, H. (2017). Türkçe dersinde ağ araştırması'na dayalı öğretim: bir eylem araştırması. } \\
\text { (Yayımlanmamış doktora tezi). Gazi Üniversitesi Eğitim Bilimleri Enstitüsü, Ankara. }\end{array}$ \\
\hline 44. & $\begin{array}{l}\text { Yamaç, A. (2015). Illkokul üçüncü sınıf öğrencilerinin yazma becerilerinin gelişiminde } \\
\text { dijital hikâyelerin etkisi. (Yayımlanmamış doktora tezi). Gazi Üniversitesi Eğitim Bilimleri } \\
\text { Enstitüsü, Ankara. }\end{array}$ \\
\hline
\end{tabular}

\section{Ek-2. İncelenen makalelerin kaynakçası}

\begin{tabular}{|c|c|}
\hline 1. & $\begin{array}{l}\text { Arıcı, N., Karacı, A. (2013). Türkçe Öğrenimi İçin Web Tabanlı Zeki Öğretim Sistemi } \\
\text { (Türkzös) ve Değerlendirmesi. Electronic Turkish Studies, 8(8), 65-87. }\end{array}$ \\
\hline 2. & $\begin{array}{l}\text { Akbaba, R. S., Tunagür, M. (2018). Bilişim Teknolojilerinin Dil Becerilerinde Kullanımı } \\
\text { Üzerine Bir İ̧̧erik Analizi. Ağrı ibrahim Çeçen Üniversitesi Sosyal Bilimler Enstitüsü } \\
\text { Dergisi, 4(2), 127-146. }\end{array}$ \\
\hline 3. & $\begin{array}{l}\text { Akçay, A., Özcan, M. F. (2012). Türkçe Öğretmeni Adaylarının Bilgisayar ve Genel Ağ } \\
\text { Terimlerinin Türkçe Karşılıklarını Bilme Yeterlikleri. Uluslararası Türkçe Edebiyat Kültür } \\
\text { Eğitim (Teke) Dergisi, 1(4), 151-161. }\end{array}$ \\
\hline 4. & $\begin{array}{l}\text { Akçay, A., Şahin, A. (2012). Webquest (Web Macerası) Öğrenme Yönteminin Türkçe } \\
\text { Dersindeki Akademik Başarı ve Tutuma Etkisi. Eğitim Bilimleri Araştırmaları Dergisi, 2(2), } \\
\text { 33-45. }\end{array}$ \\
\hline 5. & $\begin{array}{l}\text { Akın, E. (2015). Türkçe Öğretmenlerinin Kaynaştırma Öğrencilerinin Eğitiminde Çoklu } \\
\text { Ortam Araçlarından Faydalanmaya Yönelik Görüşlerinin İncelenmesi. Eğitim ve Ögrretim } \\
\text { Araştırmaları Dergisi, 4(4), 384-393. }\end{array}$ \\
\hline 6. & $\begin{array}{l}\text { Akın, E., Çeçen, M. A. (2015). Çoklu Ortam Uygulamalarına Dayalı Öğretimin 6. Sınıf } \\
\text { Öğrencilerinin Anlama Becerilerine ve Türkçe Dersi Tutumlarına Etkisi: Muş İli Örneği. } \\
\text { Uluslararası Eğitim Bilimleri Dergisi. 2(5). 285-309. }\end{array}$ \\
\hline 7. & $\begin{array}{l}\text { Aksüt, M., Er, O., Ateş, S., Balaban, S. (2013). Üniversite Tarih ve Türkçe Bölümü } \\
\text { Öğrencilerinin Biliş̧im Teknolojilerine Yönelik Görüşlerinin Incelenmesi. Eğitim } \\
\text { Teknolojileri Araştırma Dergisi, 2(2), 1-13. }\end{array}$ \\
\hline 8. & $\begin{array}{l}\text { Altunbay, M., Bıçak, N. (2018). Türkçe Eğitimi Derslerinde "Z Kuşağı" Bireylerine Uygun } \\
\text { Teknoloji Tabanlı Uygulamaların Kullanımı. Zeitschrift Für Die Welt Der Türken/Journal } \\
\text { of World of Turks, 10(1), 127-142. }\end{array}$ \\
\hline 9. & $\begin{array}{l}\text { Arslan, M., Gürdal, A. (2012). Yabancılara Görsel ve İşitsel Araçlarla Türkçe Kelime } \\
\text { Öğretim Yöntemi. Kastamonu Eğitim Dergisi, 20(1), 255-270. }\end{array}$ \\
\hline 10. & Atlı, Ş., Aksüt, M., Atar, G., Yıldız, N. (2007). Türkçe Öğretn \\
\hline
\end{tabular}




\begin{tabular}{|c|c|}
\hline 11. & $\begin{array}{l}\text { Aytan, T., Ayhan, N. H. (2018). Türkçenin Yabancı Dil Olarak Öğretiminde Dijital } \\
\text { Ortamlar. International Journal of Bilingualism Studies, 1(1), 3-37. }\end{array}$ \\
\hline 12. & $\begin{array}{l}\text { Aytan, T., Güneş, G., Çalıcı, M. A. (2018). Türkçe Öğretmeni Adaylarının Tweet Atma } \\
\text { Becerileri Üzerine Bir Araştırma. Rumelide Dil ve Edebiyat Araştırmaları Dergisi, 11, 42- } \\
58 .\end{array}$ \\
\hline 13. & $\begin{array}{l}\text { Bal, M., Uslu, E. (2018). Türkçe Öğretim Sürecinde Dijital Bölünme. Sakarya University } \\
\text { Journal of Education, 8(1), 228-245. }\end{array}$ \\
\hline 14. & $\begin{array}{l}\text { Baş, B., Yıldırım, T. (2018). Yabancılara Türkçe Öğretiminde Teknoloji Entegrasyonu. Ana } \\
\text { Dili Eğitimi Dergisi, 6(3), 827-839. }\end{array}$ \\
\hline 15. & $\begin{array}{l}\text { Başkaya, K., Tursunovic, M. (2017). Yabancı Dil Olarak Türkçe Öğretiminde İş Birlikli } \\
\text { Öğrenme ve Padlet. Aydın Tömer Dil Dergisi, 79, 87-96. }\end{array}$ \\
\hline 16. & $\begin{array}{l}\text { Becel, A. (2013). Bilişim Teknolojileri Ekseninde Yazarlık ve Yazma Becerileri Dersine } \\
\text { Yönelik Bir Değerlendirme. Electronic Turkish Studies, 8(3), 61-81. }\end{array}$ \\
\hline 17. & $\begin{array}{l}\text { Becel, A. (2014). Yabancılara Türkçe Öğretimi İçin Geliştirilen Müzikal Beyin Eğitmeni: } \\
\text { Earworm (S). Eğitim ve Öğretim Araştırmaları Dergisi, 3(3), 99-106. }\end{array}$ \\
\hline 18. & $\begin{array}{l}\text { Bircan, E. (2012). Türkçe Öğretmeni Adaylarının Öğretim Teknolojilerini Kullanmaya } \\
\text { Yönelik Öz Güvenleri. Adıyaman Üniversitesi Sosyal Bilimler Enstitüsü Dergisi, 9, 77-87. }\end{array}$ \\
\hline 19. & $\begin{array}{l}\text { Bolat, Y. (2016). Ters Yüz Edilmiş Sınıflar ve Eğitim Bilişim Ağı (EBA). Journal of Human } \\
\text { Sciences, 13(2), 3373-3388. }\end{array}$ \\
\hline 20. & $\begin{array}{l}\text { Can, E., Topçuoğlu, F. (2018). Eğitim Bilişim Ağı Kullanımının (EBA) Ortaokul } \\
\text { Öğrencilerinin Türkçe Dersine Yönelik Tutumlarına Etkisi. Eskişehir Osmangazi } \\
\text { Üniversitesi Türk Dünyası Uygulama ve Araştırma Merkezi Eğitim Dergisi, 3(1), 61-68. }\end{array}$ \\
\hline 21. & $\begin{array}{l}\text { Candeğer, Ü., Mete, F., Büyükköse, Ş. (2017). Millî Eğitim Bakanlı̆̆ Eğitim Bilişim } \\
\text { Ağı'nda Bulunan Kavram Haritalarının Incelenmesi. E-Kafkas Eğitim Araştırmaları } \\
\text { Dergisi, 4(1), 11-25. }\end{array}$ \\
\hline 22. & $\begin{array}{l}\text { Coşkun, M. V. (2009). Ana Dili Eğitiminde Parçalarüstü Birimlerin Önemi ve Teknoloji } \\
\text { Destekli Olarak Kavratılması. Bilig, 48, 41-52. }\end{array}$ \\
\hline 23. & $\begin{array}{l}\text { Dargut, T., Çelik, G. (2014). Türkçe Öğretmeni Adaylarının Eğitimde Teknoloji } \\
\text { Kullanımına İlişkin Tutum ve Düşünceleri. Ana Dili Eğitimi Dergisi, 2(2), 28-41. }\end{array}$ \\
\hline 24. & $\begin{array}{l}\text { Demir Atalay, T. (2016). Türkçe Öğretmen Adaylarının Teknolojik Pedagojik Alan Bilgisi } \\
\text { Durumlarının Çeşitli Değişkenlerle İlişkisi. Electronic Turkish Studies, 11(9), 247-266. }\end{array}$ \\
\hline 25. & $\begin{array}{l}\text { Demir, D., Özdinç, F., Ünal, E. (2018). Eğitim Bilişim Ağı (EBA) Portalına Katılımın } \\
\text { İncelenmesi. Erzincan Üniversitesi Eğitim Fakültesi Dergisi, 20(2), 407-422. }\end{array}$ \\
\hline 26. & $\begin{array}{l}\text { Demirer, V., Baki, Y. (2018). Türkçe Öğretmeni Adaylarının Dijital Öyküleme Sürecine } \\
\text { İlişkin Görüşleri ve Algıları. Kuramsal Eğitimbilim Dergisi, 11(4), 718-747. }\end{array}$ \\
\hline 27. & $\begin{array}{l}\text { Duran, E., Özen, N. E. (2018). Türkçe Derslerinde Dijital Okuryazarlık. Türkiye Eğitim } \\
\text { Dergisi, 3(2), 31-46. }\end{array}$ \\
\hline 28. & $\begin{array}{l}\text { Dündar, Ş. N., Kara, M. (2019). Yabancı Dil Olarak Türkçenin Öğretiminde Dijital } \\
\text { Platformların Kullanılmasına Yönelik Öğretmenlerin Görüşleri. 21. Yüzyılda Eğitim ve } \\
\text { Toplum, 8(24), 557-579. }\end{array}$ \\
\hline 29. & $\begin{array}{l}\text { Ertem, I. S. (2016). Oyun Temelli Dijital Ortamlar ve Türkçe Öğretiminde Kullanımına } \\
\text { i̇lişkin Sınıf Öğretmenlerinin Görüşleri. Mjer/Aead, 20,1-10. }\end{array}$ \\
\hline 30. & $\begin{array}{l}\text { Fidan, M. (2019). Türkçenin Yabancı Dil Olarak Öğretiminde İnternetin Kullanılabilirliği } \\
\text { Üzerine Bir Araştırma. Turkish Studies Educational Sciences, 14(3), 565-578. }\end{array}$ \\
\hline 31. & $\begin{array}{l}\text { Gedik, M. (2015). Türkçe Öğretmeni Adaylarının Medya Okuryazarlığına İlişkin } \\
\text { Görüşleri. Atatürk Üniversitesi Türkiyat Araştırmaları Enstitüsü Dergisi, 54, 779-809. }\end{array}$ \\
\hline 32. & $\begin{array}{l}\text { Gezgin, D., Silahsızoğlu, E. (2016). Bilişim Teknolojileri Kullanımının Türkçeye } \\
\text { Etkileri. Turkish Online Journal of Qualitative Inquiry, 7(1), 28-46. }\end{array}$ \\
\hline 33. & İskender, H. (2016). Eğitim Bilişim Ağı'nda Bulunan 7. Sınıf Türkçe Dersi Vide \\
\hline
\end{tabular}


Türkçe eğitiminde bilişim ve teknoloji kullanımına yönelik araştırmaların konu alanı ve yöntem yönünden analizi

\begin{tabular}{|c|c|}
\hline & $\begin{array}{l}\text { İlköğretim Türkçe Dersi (6, 7, 8. Sınıflar) Öğretim Programıyla Uyumu. Adıyaman } \\
\text { Üniversitesi Sosyal Bilimler Enstitüsü Dergisi, 8(24), 1043-1068. }\end{array}$ \\
\hline 34. & $\begin{array}{l}\text { İskender, M. E., Gücüyeter, B. (2019). Yabancı Dil Olarak Türkçe Yazma Öğretiminde } \\
\text { Anlık Mesajlaşma Programlarının Kullanımı: Whatsapp Uygulaması Örneği. Sosyal } \\
\text { Bilimler Araştırmaları Dergisi, 14(2), 571-590. }\end{array}$ \\
\hline 35. & $\begin{array}{l}\text { Kalaycı, D., Durukan, E. (2018). Mobil Cihaz Dilinin Yabancı Dil Olarak Türkçe } \\
\text { Öğrenimine Etkisine ilişkin Öğrenci Görüşleri: Trabzon TÖMER Örneği. Journal of } \\
\text { International Social Research, 11(59), 771-778. }\end{array}$ \\
\hline 36. & $\begin{array}{l}\text { Karakuş, N., Ucuzsatar, N., Karacaoğlu, M. Ö., Esendemir, N., Bayraktar, D. (2020). } \\
\text { Türkçe Öğretmeni Adaylarının Uzaktan Eğitime Yönelik Görüsleri. Rumelide Dil ve } \\
\text { Edebiyat Araştırmaları Dergisi, 19, 220-241. }\end{array}$ \\
\hline 37. & $\begin{array}{l}\text { Karasakaloğlu, N., Saracaloğlu, A. S., Uça, S. (2011). Türkçe Öğretmenlerinin Teknoloji } \\
\text { Tutumları ile Bilgi Teknolojilerini Kullanma Düzeylerinin İncelenmesi. Mersin Üniversitesi } \\
\text { Eğitim Fakültesi Dergisi, 7(2), 26-36. }\end{array}$ \\
\hline 38. & $\begin{array}{l}\text { Katrancı, M., Uygun, M. (2013). Sınıf Öğretmenlerinin Türkçe Derslerinde Teknoloji } \\
\text { Kullanımına Yönelik Görüşleri. Adıyaman Üniversitesi Sosyal Bilimler Enstitüsü Dergisi, } \\
\text { 11,773-797. }\end{array}$ \\
\hline 39. & $\begin{array}{l}\text { Kırkkılıç, H. A., Şahin, A. (2007). Temel Dil Becerilerinin Geliştirilmesinde Eğitim } \\
\text { Teknolojisinin Kullanımı. Uluslararası Asya ve Kuzey Afrika Çalışmaları Kongresi (Icanas } \\
\text { 38). }\end{array}$ \\
\hline 40. & $\begin{array}{l}\text { Kurudayıoğlu, M., Bal, M. (2014). Ana Dili Eğitiminde Dijital Hikâye Anlatımlarının } \\
\text { Kullanımı. Sakarya Üniversitesi Eğitim Fakültesi Dergisi, (28), 74-95. }\end{array}$ \\
\hline 41. & $\begin{array}{l}\text { Kurudayıoğlu, M., Soysal, T. (2020). } 2018 \text { Türkçe Dersi Öğretim Programı'nın Dijital } \\
\text { Yetkinlik Bakımından İncelenmesi. Mehmet Akif Ersoy Üniversitesi Eğitim Fakültesi } \\
\text { Dergisi, 54, 184-199. }\end{array}$ \\
\hline 42. & $\begin{array}{l}\text { Kurudayıoğlu, M., Tüzel, S. (2010). 21. Yüzyıl Okuryazarlık Türleri, Değişen Metin Algısı } \\
\text { ve Türkçe Eğitimi. Türklük Bilimi Araştırmaları, 28, 283-298. }\end{array}$ \\
\hline 43. & $\begin{array}{l}\text { Maden, A. (2019). Türkçe Öğretmeni Adaylarının Mobil iletişim Alışkanlıkları: Whatsapp } \\
\text { Örneği. Elektronik Sosyal Bilimler Dergisi, 18(72), 1797-1811. }\end{array}$ \\
\hline 44. & $\begin{array}{l}\text { Maden, S. (2012). Ekran Okuma Türleri ve Türkçe Öğretmeni Adaylarının Ekran } \\
\text { Okumaya Yönelik Görüşleri. Dil ve Edebiyat Eğitimi Dergisi, 1(3), 1-16. }\end{array}$ \\
\hline 45. & $\begin{array}{l}\text { Maden, S., Önal, A. (2018). Elektronik Bilişim Ağı’ndaki Ortaokul Türkçe Dersi } \\
\text { İçeriklerinin Kullanımı Üzerine Bir Araştırma. Dil Eğitimi ve Araştırmaları Dergisi, 4(2), } \\
\text { 101-121. }\end{array}$ \\
\hline 46. & $\begin{array}{l}\text { Maden, S., Önal, A. (2020). Elektronik Bilişim Ağı (EBA) İçerik Modülündeki Türkçe Dersi } \\
\text { İle İlgili Dokümanlar. Eğitim Teknolojisi Kuram ve Uygulama, 10(1), 25-50. }\end{array}$ \\
\hline 47. & $\begin{array}{l}\text { Maden, S., Banaz, E., Maden, A. (2018). Türkçe Öğretmeni Adaylarının Dijital } \\
\text { Ortamlardaki Yazma Alışkanlıkları. Eğitim ve Öğretim Araştırmaları Dergisi, 7(1), 103- } \\
\text { 112. }\end{array}$ \\
\hline 48. & $\begin{array}{l}\text { Maden, S., Maden, A., Banaz, E. (2018). Ortaokul 5. Sınıf Türkçe Ders Kitaplarının Dijital } \\
\text { Okuryazarlık Bağlamında Değerlendirilmesi. Journal of International Social Research, } \\
\text { 11(55), 685-698. }\end{array}$ \\
\hline 49. & $\begin{array}{l}\text { Moralı, G. (2018). Yabancı Dil Olarak Türkçe Öğretiminde Blogların Kullanımına Yönelik } \\
\text { Kuramsal Bir Çalışma. Turkophone, 5(1), 41-50. }\end{array}$ \\
\hline 50. & $\begin{array}{l}\text { Ateş, M., Çerçi, A., Derman, S. (2015). Eğitim Bilişim Ağında Yer Alan Türkçe Dersi } \\
\text { Videoları Üzerine Bir İnceleme. Sakarya University Journal of Education, 5(3), 105-117. }\end{array}$ \\
\hline 51. & $\begin{array}{l}\text { Oğraş, R. (2015). Pedagojik Web Tabanlı Türkçe Öğretimi Üzerine Çağdaş Yaklaşımlar ve } \\
\text { Uygulamalar. Ayrıntı Dergisi, 3(25), 58-65. }\end{array}$ \\
\hline 52. & $\begin{array}{l}\text { Oğraş, R., Arı, M., Ateş, B., Ünal, R. (2017). Çevrim içi Türkçe Öğretiminde Sözlük } \\
\text { Kullanımı. Ayrıntı Dergisi, 49, 49-52. }\end{array}$ \\
\hline
\end{tabular}




\begin{tabular}{|c|c|}
\hline 53. & $\begin{array}{l}\text { Okur, A. (2012). Türkçe Ders Kitaplarında Bilim ve Teknoloji. Electronic Turkish Studies, } \\
\text { 7(4), 2413-2429. }\end{array}$ \\
\hline 54. & $\begin{array}{l}\text { Özbay, M., Çelik, M.E. (2013). Türkçe Öğretmeni Adaylarının Bilgisayar Kullanma } \\
\text { Yeterliklerine İlişkin Görüşlerinin Değerlendirilmesi. Ana Dili Eğitimi Dergisi, 1(1), 107- } \\
\text { 115. }\end{array}$ \\
\hline 55. & $\begin{array}{l}\text { Özbay, M., Özdemir, O. (2014). Türkçe Öğretim Programı İcin Bir Öneri: Dijital } \\
\text { Okuryazarlığa Yönelik Amaç ve Kazanımlar. Okuma Yazma Eğitimi Araştırmaları, 2(2), } \\
\text { 31-40. }\end{array}$ \\
\hline 56. & $\begin{array}{l}\text { Özdemir, O. (2017). Türkçe Öğretiminde Dijital Teknolojilerin Kullanımı ve Bir Web } \\
\text { Uygulaması Örneği. Electronic Turkish Studies, 12(4), 427-444. }\end{array}$ \\
\hline 57. & $\begin{array}{l}\text { Pilancı, H., Çalışkan, H., Aydın, C. H., Karadağ, N., Söker, N., Saltık, O., Kip Kayabaş, B. } \\
\text { (2015). Uzaktan Türkçe Öğretim Programı (Tsp): Hazırlık, Uygulama, Sorunlar ve } \\
\text { Çözümler. Turkish Studies, 10(11), 1277-1296. }\end{array}$ \\
\hline 58. & $\begin{array}{l}\text { Pilancı, H. (2009). Uzaktan Türkçe Öğrenen Yabancıların Türkçeyi İletişim Aracı Olarak } \\
\text { Kullanabilme Yeterlikleri. Dil ve Dilbilimi Çalışmaları Dergisi, 5(2), 49-61. }\end{array}$ \\
\hline 59. & $\begin{array}{l}\text { Pilancı, H. (2018). Açık ve Uzaktan Türkçe Öğrenenlerde Etkileşim: Eşzamansız Illetişimde } \\
\text { Öğretim Diyalogları. Uluslararası Beşeri Bilimler ve Eğitim Dergisi, 4(7), 75-90. }\end{array}$ \\
\hline 60. & $\begin{array}{l}\text { Sevim, O., Toyran, M. (2020). Lise Öğrencilerinin Tablet Bilgisayar Destekli Türkçe } \\
\text { Öğrenme Tutum ve Görüşlerinin İncelenmesi. Kuram ve Uygulamada Sosyal Bilimler } \\
\text { Dergisi, } 4(1), 56-65 \text {. }\end{array}$ \\
\hline 61. & $\begin{array}{l}\text { Şahin, A., Akçay, A. (2011). Türkçe Öğretmeni Adaylarının Bilgisayar Destekli Eğitime } \\
\text { İlişkin Tutumlarının Incelenmesi. Electronic Turkish Studies, 6(2), 909-918. }\end{array}$ \\
\hline 62. & $\begin{array}{l}\text { Şen, Ü. (2016). Yabancı Dil Olarak Türkçe Öğretiminde Uzaktan Eğitim Programları. } \\
\text { Journal of Kirsehir Education Faculty, 17(2), 411-428. }\end{array}$ \\
\hline 63. & $\begin{array}{l}\text { Temizyürek, F., Ünlü, N. A. (2015). Dil Öğretiminde Teknolojinin Materyal Olarak } \\
\text { Kullanımına Bir Örnek: "Flipped Classroom”. Bartın Üniversitesi Eğitim Fakültesi Dergisi, } \\
\text { 4(1), 64-72. }\end{array}$ \\
\hline 64. & $\begin{array}{l}\text { Timur, B., YIImaz, Ş., İşseven, A. (2017). Ortaokul Öğrencilerinin Eğitim Bilişim Ağı (EBA) } \\
\text { Sistemini Kullanmalarına Yönelik Görüşleri. Asian Journal of Instruction, 5(1), 44-54. }\end{array}$ \\
\hline 65. & $\begin{array}{l}\text { Tiryaki, E. N., Karakuş, O. (2019). Türkçe Öğretmeni Adaylarının Dijital Uygulama } \\
\text { Aracılığıyla Okuduğunu Anlama Becerisinin İncelenmesi. Journal of Advanced Education } \\
\text { Studies, 1(1), 1-11. }\end{array}$ \\
\hline 66. & $\begin{array}{l}\text { Tiryaki, E. N., Demir, A. (2020). Türkçe Öğretmeni Adaylarının Geri Bildirimlerinde } \\
\text { Teknoloji Destekli Öğretim ile Geleneksel Öğretim Yönteminin Etkisi. Uluslararası Dil, } \\
\text { Eğitim ve Sosyal Bilimlerde Güncel Yaklaşımlar Dergisi (Caless), 2(1), 276-303. }\end{array}$ \\
\hline 67. & $\begin{array}{l}\text { Türker, M. S. (2019). Yabancı Dil Olarak Türkçe Öğretenlerin Eğitim Teknolojisi } \\
\text { Standartları Öz-Yeterlik Algılarının İncelenmesi. Ana Dili Eğitimi Dergisi, } 7(3), \text { 574-596. }\end{array}$ \\
\hline 68. & 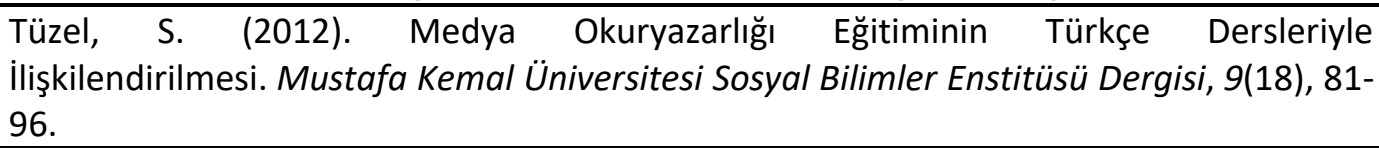 \\
\hline 69. & $\begin{array}{l}\text { Ünlü, B. F. (2019). Yabancı Dil Olarak Türkçe Öğretiminde Sanal Gerçekliğin Amaç Odaklı } \\
\text { Dil Öğretimine Etkisi. Hacettepe Üniversitesi Yabancı Dil Olarak Türkçe Araştırmaları } \\
\text { Dergisi, 5, 57-76. }\end{array}$ \\
\hline 70. & $\begin{array}{l}\text { Yaman, H. (2007). Türkçe Öğretmeni Adaylarının "Öğretim Teknolojileri ve Materyal } \\
\text { Geliştirme" Dersi Bağlamında Türkçe Öğretiminde Teknoloji Kullanımına İlişkin Yeterlilik } \\
\text { ve Algıları. Hayef Journal of Education, 4(1), 57-71. }\end{array}$ \\
\hline 71. & $\begin{array}{l}\text { Yaman, H., Erdoğan, Y. (2007). Internet Kullanımının Türkçeye Etkileri: Nitel Bir } \\
\text { Araştırma. Journal of Language and Linguistic Studies, 3(2), 237-249. }\end{array}$ \\
\hline 72. & $\begin{array}{l}\text { Yaman, H., Demirtaş, T., Aydemir, Z. (2013). Türkçe Öğretmeni Adaylarının Dijital } \\
\text { Pedagojik Yeterlilikleri. Electronic Turkish Studies, 8(8), 1407-1419. }\end{array}$ \\
\hline
\end{tabular}


Türkçe eğitiminde bilişim ve teknoloji kullanımına yönelik araştırmaların konu alanı ve yöntem yönünden analizi

73. Yazar, i. (2019). Türkçe Öğretiminde ve Temel Dil Becerilerinin Kazanımında Dijital Teknoloji Uygulamalarının Yeri ve Önemi. The Journal of International Social Research, 12(64). 612-623.

74. Yıılız, S. (2020). Türkçe Öğretiminde Teknolojik Materyal Kullanımı. Journal of World of Turks/Zeitschrift Für Die Welt Der Türken, 12(1), 95-115.

75. Yılmaz, F., Babacan, G. (2015). Yabancı Dil Olarak Türkçe Öğretiminde Podcast Kullanımı. Electronic Turkish Studies, 10(3), 1153-1170.

76. Yılmaz, Y., Üstündağ, M. T., Güneş, E., Çalışkan, G. (2017). Dijital Hikâyeleme Yöntemi ile Etkili Türkçe Öğretimi. Eğitim Teknolojisi Kuram ve Uygulama, 7(2), 254-275. 